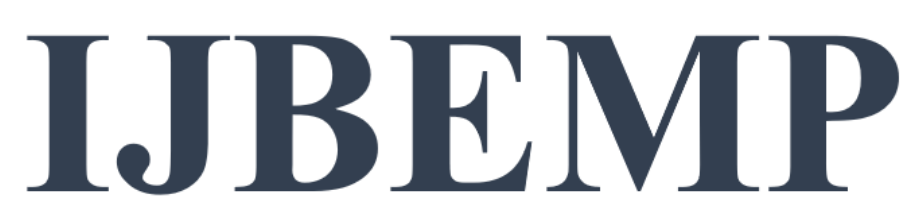

ISSN: $2458-8978$ E-ISSN : 2458-8978

Yıl Year: 6

Cilt Volume: 5

International Journal of Business, Economics and Management Perspectives

Sayı Issue : 1 Uluslararası İșletme, Ekonomi ve Yönetim Perspektifleri Dergisi

\title{
KATILIM BANKALARINA GENEL BAKIŞ VE GELENEKSEL PERFORMANS DEĞERLEME YÖNTEMI OLARAK ORAN ANALIZİ UYGULAMASI
}

\section{Fatma YÖRÜK EREN}

Doktora Öğrencisi, Süleyman Demirel Üniversitesi, Sosyal Bilimler Enstitüsü, Isparta, Türkiye, yoruk.fatma@hotmail.com, ORCID- ID: 0000-0003-0687-8749.

\section{Oğuzhan ÇARIKÇI}

Doç. Dr., Süleyman Demirel Üniversitesi, İktisadi ve İdari Bilimler Fakültesi, İşletme Anabilim Dalı, Muhasebe ve Finansman Bölümü, Isparta, Türkiye, oguzhancarikci@sdu.edu.tr, ORCID- ID: 0000001-8709-9071. 


\title{
KATILIM BANKALARINA GENEL BAKIŞ VE GELENEKSEL PERFORMANS DEĞERLEME YÖNTEMİ OLARAK ORAN ANALİZI UYGULAMASI \\ ÖZET
}

Bankalar ülke ekonomisinde ve finans sektöründe denge sağlayan önemli kuruluşlardır. Katılım bankaları, Körfez ülkelerinin Müslüman coğrafyasında 1960’lı yıllarda faizsiz bankacılık adı altında varlığını göstermiştir. Tasarrufların biriktirilmesi ve değerlendirilmesi noktasında, toplumsal bir ihtiyacın karşılanmasına olanak sağlamıștır. Âtıl kalan birikimlerin faizsizlik ilkesi ile ülke ekonomisine dolayısıyla üretime aktarılmasında rol üstlenmektedir. Son zamanlarda bankacılık sistemi içinde katılım bankacılığının sektör içindeki payının artması dikkat çekicidir. Katılım bankaları da bu sektördeki yerini almaktadır. Katılım bankaları, Dünyada ve Türkiye'de yaygınlık göstererek, faizsiz bankacılık anlayışı ile kalıcı yer edinmektedir.

Çalışmada; katılım bankalarına kavramsal çerçeveden bakılarak, amaçları, tarihi ve gelişim sürecinden bahsedilmiştir. Dünyada ve Türkiye'de katılım bankacığı gelişim süreci konuları işlenmiştir. Katılım bankacılığı ihtiyacının ortaya çıkış sebeplerinden bahsedilmiştir. Katılım bankacılığının yapısal özellikleri, faiz ve kâr payı kavramları, fon toplama ve fon kullandırma faaliyetleri sürecinden söz edilmiştir. Türkiye'de 2019 y1lında faaliyette bulunan Albaraka Türk Katılım Bankası, Kuveyt Türk Katılım Bankası, Türkiye Finans Katılım Bankası, Ziraat Katılım Bankası, Vakıf Katılım Bankası ve Türkiye Emlak Katılım Bankası olmak üzere altı bankanın verileri incelenmiştir. 01 Ocak 2019- 31 Aralık 2019 hesap dönemine ait konsolide finansal tablolar ve bağımsız denetim raporları ile konsolide kâr/ zarar tabloları kullanılmıştır. Oran analizinde; sermaye yeterlilik, aktif kalitesi, yönetim kalitesi, kârlılık, likidite ve piyasa riskine duyarlılık oranları hesaplanmıştır. Katılım bankalarının oran değerleri verileri karşılaştırılması yapılarak, bankaların performans değerlendirilmesi yapılmıştır.

Anahtar Kelimeler: Katılım Bankaları, Oran Analizi, Performans Analizi.

JEL Sinıflandırma Kodları: C02, G21, G30, F65.

\section{OVERVIEW OF PARTICIPATION BANKS AND APPLICATION OF RATIO ANALYSIS AS A TRADITIONAL PERFORMANCE ASSESSMENT METHOD}

\begin{abstract}
Banks are important institutions that provide balance in the country's economy and finance sector. Participation banks have existed under the name of interest-free banking in the Muslim geography of the Gulf countries in the 1960s. It has enabled a social need to be met at the point of accumulating and utilizing savings. It plays a role in the transfer of idle savings to the country's economy and therefore to production, with the principle of interestfree savings. It is noteworthy that the share of participation banking in the banking system has increased recently. Participation banks are also taking their place in the sector. Participation banks are showing prevalence in the World and Turkey, acquire permanent place with the understanding of interest-free banking.

In the study, looking at participation banks from a conceptual framework, their aims, history and development process are mentioned. Participation banking in Turkey and the World development issues are handled. The reasons for the emergence of the need for participation banking are mentioned. Structural features of participation banking, concepts of interest and dividends, fund raising and fund allocation processes are mentioned. Albaraka Türk Katılım Bank, Kuveyt Türk Katılım Bank, Türkiye Finans Katılım Bank, Ziraat Katılım Bank, Vakıf Katılım Bank and Türkiye Emlak Katılım Bank including six banks of the data have been analyzed in Turkey operating in 2019. Consolidated financial statements and independent audit reports and consolidated profit / loss statements for the fiscal period of 01 January 2019- 31 December 2019 have been used. In ratio analysis, capital adequacy, asset quality, management quality, profitability, liquidity and market risk sensitivity ratios are calculated. Performance evaluation of banks was made by comparing the ratio values of participation banks.
\end{abstract}

Keywords: Participation Banks, Ratio Analysis, Performance Analysis.

JEL Classification Codes: C02, G21, G30, F65. 


\section{GİRIŞ̧}

Katılım bankacılığı sektörü faizsizlik prensibi ile diğer bankacılık sektöründen ayrılmaktadır. Dünya'da ticari faaliyetlerin hızla ilerlemesi, rekabetin, küreselleşmenin ve ihtiyaçların artması ile katılım bankacılığı sistemi de gelişme göstermiştir.

Katılım bankalarının finansal durumları farklı çıkar gruplarını yakından ilgilendirmektedir. Hisse senedi yatırımı yapmak arzusunda olanlar, çeşitli işletme yöneticileri ve kredi kurumları finansal durumlarla ilgilenen kesimlerden bazılarıdır. Finansal analizin yapılması, yatırım kararlarının sağlıklı ve doğru alınabilmesi açısından oldukça gereklidir. Bireyler ve örgütler işletmelerin mali tablolarını, büyük oranda finansal analiz yoluyla değerlendirmektedir. Ayrıca, finansal verilerin birbirleriyle olan ilişkisi de incelenebilmektedir. Bir işletme olan katılım bankalarının da aktüel bilgilerinin büyük bir kısmına bilanço ve gelir tablosu sayesinde ulaşılmaktadır. Bazı önemli istatistiklerin genel görünümü elde edilmek istenildiğinde oran analizi kullanılmaktadır. Elde edilen ölçütler izlenerek banka performansındaki önemli trendler yakalanabilmektedir.

Gelecekte katılım bankacıllğı sektörüne yön verecek yöneticilerin ve paydaşların, banka finansal tablo analizlerine ve sonuçlarına önem vermeleri gerekmektedir. Bu çalışmanın, son zamanlarda ve güncel olarak, Türkiye'de faaliyet gösteren altı katılım bankasının finansal oran analizleri ve sonuçları hakkında 1şık tutabilecek çalışmalardan biri olacağı düşünülmektedir.

Çalışmada, katılım bankacılığının gelişiminde tarihsel süreçten bahsedilmiştir. Türkiye'de katılım bankacığı anlayışı ve katılım bankalarının ortaya çıkışındaki sebepler işlenmiştir. Fon toplama ve kullandırma yöntemleri ele alınmıştır. Literatür incelemesi ve oran analizi ile ilgili bir uygulama yapılmıştır.

\section{KATILIM BANKACILIĞININ TARİHSEL GELIŞSIM SÜRECI}

İslam'ın yükselişi, yeni bir uygarlık getirmiştir. Bu nedenle İslam hukukunun temelini oluşturacak ekonomik, politik, sosyal ve adli alanlarda değişiklikler yapılmıştır. İslam'ın ilk yıllarında, modern bankacılık işlemlerine benzer bazı bankacılık faaliyetlerinin olduğu, bazı tarih kitaplarında yazılmıştır. Dahası bu kitaplar İslam'ın en ünlü şahsiyetlerinden biri olan Al-Zubair bin El-Awam'ın, insanlardan İslam hukukuna göre mevduat kabul edip bu mevduatları borç şeklinde ya da yatırıma dönüştürme şeklinde kullandığını ortaya çıkarmaktadır. Bazı çağdaş bilim adamları, bu duruma AlZubair Bank demişlerdir. Buna ek olarak, İslam'ın 1. yüzyılında yani MS. 800'lü yıllarda 4. Emevi Halifesi Marwan bin El Hakam'ın hüküm sürdüğü sıralarda devletin askerlerine ve çalışanlarına ödeme yöntemi olarak Sukuk kullanılmaktadır (Alharbi, 2013: 10).

Modern anlamda katılım bankacılı̆̆ının başlangıcını belirlemek zordur fakat Mısır'da ilk kez gerçekleştiği konusunda fikir birliği sağlanmaktadır. Kar paylaşımına dayanan bir tasarruf bankası biçiminde faaliyet göstermiştir (Etab, 2016: 21).

Modern İslami bankacılığın temeli 1940'ların ortalarında tartışılmıştır. Daha sonra, İslami bankacılık modeli 1950 'lerin ortalarında ortaya çıkmış olmasına rağmen faizsiz bankacılık için kapsamlı ve ayrıntılı kavramlar ancak 1960 'larda ortaya çıkmıştır. İslami bankacılıkta ilk deneyim 1963 'te Mısır Mit Ghamr'da örtülü olarak kurulmuştur. Model İslami ilkelere, yani Riba'nın yasaklanmasına uyacak şekilde modifiye edilmiş bir Alman tasarruf bankası olmuştur (Billah, 2007: 401). Tasarruf bankası özelliğindeki bu bankanın faaliyetleri 1967 yılından sonra bitmiş ve faizli sistemle çalışan "Mısır Ulusal Bankası" tarafından devralınmıştır (Tiby, 2011: 4)

Faizsiz banka ismiyle faaliyete geçen ilk kurum, 1971'de yine Misır'da kurulan Nasser Social Bank'tır. Her ne kadar bankanın temel amacı öğrencilere burs vermek, fakir insanlara yardım etmek ve kâr paylaşımı temelinde küçük projelere kredi sağlamak gibi sosyal nitelikli olsa da Müslüman iş adamlarına fikir verme açısından önem arz etmektedir. Bu oluşumdan esinlenen bir grup iş adamı, 1975 yılında Birleşik Arap Emirlikleri'nin (BAE) Dubai şehrinde Dubai İslam Bankası'nı kurmuştur. Modern anlamda kurulan ilk İslami banka olan Dubai İslam Bankas1; \%20 oranında BAE, \%10 oranında Kuveyt hükümetinden kamusal sermaye desteği sağlayarak özel banka statüsünde kurulmuştur. (Iqbal ve Molyneux, 2005: 37) 
1960'lardan beri İslami bankacılık sistemi üzerinde çalışılmış olmasına rağmen İslam Kalkınma Bankası (IKB) kurulana kadar çalışmalar genel olarak teoride kalmıştır. Uluslararası bir finansal kurum olan İKB, üye ülkeler arasında ekonomik iş birliğini ve sosyal gelişmeyi teşvik etmek ve güçlendirme maksadıyla kurulmuştur. İKB'nın kuruluşunun ardından başta Orta Doğu olmak üzere bütün dünyada pekçok İslami banka kurulmaya başlanmıştır. İslami bankalar da konvansiyonel bankaların dinamik bir alternatifi haline gelmiştir (Okumuş, 2005: 52).

İslami bankalar Müslüman ve Müslüman olmayan ülkelerde yapı ve sayı açısından günden güne büyüme kaydetmiştir. Müslümanlara ve İslami kurallara özel olarak yapılandırılmış olmalarına rağmen, şaşırtıcı bir şekilde \%40'1 Müslüman olmayan müşterilerden oluşan İslami bankalar bulunmaktadır (Ariff, 2014: 733).

\section{KATILIM BANKACILIĞIN TÜRKIYYE'DE GELISŞIM SÜRECI}

Katılım bankacığı sisteminin, ülkemizde ortaya çıkmasında, 1970'li yıllarda hem tercüme edilerek yayınlanmış teorik yazınlar hem de pratik uygulamalar etkili olmuştur. Bu uygulamalardan en önemlisi, 1970'lerde yurt dışında çalışan işçilerin kazandığı paralarla işçi şirketleri kurulmuştur. Bu gelişmeler sayesinde, ekonomik alandaki arayışa cevap olarak katılım bankacığ 1 için destek olmuştur. Faizli işlemlere yanaşmak istemeyen yurt dışı çalışanlarının, ülkenin iktisadi hayatına katılma isteği ile şirketleşme başlamış, istedikleri amaca ulaşamamış olsa da büyük miktarda bir döviz kaynağının olduğunun farkına varılmıştır. Bu kaynakları finans sistemine çekmek için katılım bankacı̆̆ 1 düşüncesi güçlenmiştir. $\mathrm{Bu}$ süreçte, tasarruf kaynaklarını faizsiz olarak değerlendirmek isteyen kişilere ve KOBİ'lere hizmet etmek için, 1975 yılında kurulup, çalışmalarını 1978'e kadar sürdüren Devlet Sanayi İşçi Yatırım Bankası (DESiYAB)'nın da çok önemli tecrübe kazandırdığı bilinmektedir. Ulusal ve uluslararası düzeydeki ekonomik ve siyasal gelişmelerin yanında, ilmi gelişmelere paralel, ülkemizde İslami usullere uygun çalışan katılım bankacığı geçiş çalışmalarına başlanmıştır. 1980'li yılların başında, liberal ekonomik anlayışla birlikte, dışa açık iktisadi sisteme ve rekabete dayalı sisteme geçişle birlikte ve bu kapsamdaki katılım bankacığına geçiş de başlatılmıştır (Canbaz, 2012: 167).

Türkiye'de katılım bankacılığının kurulması 33 yıl öncesine dayanmaktadır. Öncelikle, ÖFK (Özel Finans Kurumu) olarak 1984’te Albaraka Türk kurulmuş, arkasından Faisal Finans kurulmuştur. 2001 yılında, Türkiye Katılım Bankaları Birliği, ÖFK'larını temsil etmesi maksadıyla kurulmuştur. Esas dönüm noktası, ÖFK'ların 2005 yılında banka statüsüne alınmasıyla gerçekleşmiştir. ÖFK'ları artık Katılım Bankası olarak adlandırılmıştır. 2005 yılı öncesine kadar katılım bankaları, iktisadi krizlerin etkisi ve gerekli mevzuat düzenlemesinin olmayışı sebebiyle, aktif büyüklükleri ve ürün çeşitlilikleri açısından geliş̧me sağlayamamışlardır. 2005 yılından sonra katılım bankacığı sektörünün önü açılmış, gerekli mevzuat değişiklikleri yapılmıştır (TKBB, 2015: 4).

Ülkemizde katılım bankacılığı, özellikle emtia ticareti ve finansal kiralama alanlarında daha çok faaliyette olan, asıl odak noktasını ticari ve üretim faaliyetlerinin oluşturduğu faiz dışı bankacılık olarak veya fon toplanması, riske dayalı kâr veya zarara katılma ilişkisine bağlayan bir sistem olarak görülebilmektedir (Apak ve Açıkgöz, 2011: 72).

Türkiye'de; Albaraka Türk Katılım Bankası A.Ş. 1984, Kuveyt Türk Katılım Bankası A.Ş. 1989, Türkiye Finans Katılım Bankası A.Ş. 2005, Ziraat Katılım Bankası Anonim Şirketi 2015, Vakıf Katılım Bankası 2016, Türkiye Emlak Katılım 2019 tarihlerinde kurulmuştur (www.tkbb.org.tr).

\section{SİSTEM OLARAK KATILIM BANKACILIĞI FAALIYYET BİÇIMLERİ}

\subsection{Katılım Bankacılığı Fon Toplama Faaliyetleri}

Geleneksel bankalar gibi katılım bankalarında da fon kaynaklarının büyük bir kısmı, mevduat sahiplerinin paralarına bağlı olmakta fakat geleneksel bankaların aksine katılım bankaları faiz üzerinden hiçbir getiriye izin vermemektedir. Katılım bankaları mevduatların nominal değerini bile garanti etmemektedir. Çünkü katılım bankalarının faaliyeti kâr veya zarar paylaşımı düzenine bağlıdır. Bu özellik ağırlıklı olarak yatırım hesapları ve vadeli hesaplarda da geçerlidir (Schéele, 2002: 22). 


\subsection{1. Özel Cari Hesaplar}

Katılım bankaları, geleneksel bankaların yaptığı gibi müşterilerinden cari hesaplar üzerinden mevduat kabul etmektedir. Bu hesap vadesiz hesap olarak bilinmektedir. Yatırılan miktar herhangi bir bildirimde bulunmaksızın talep üzerine müşterilere ödenmektedir. Cari hesaplardaki mevduatlar İslami bankaların kendi riskleri olduğundan, cari hesap sahipleri katılım bankası tarafından kazanılan kârdan herhangi bir pay alma hakkına sahip değildir (Alam, 2000: 4).

Özel cari hesaplar, istenildiği zaman kısmen veya tamamen paranın geri çekilebildiği vadesiz hesaplardır. Bu vadesiz hesaplara, katılım bankaları hiçbir şekilde kâr payı, faiz, vb. herhangi bir ödemede bulunmamaktadır (Kalayc1, 2013: 12).

Özel cari hesaplar herhangi bir reel getirisi olmayan vadesiz hesaplardır. Normal şartlarda vadesiz mevduat hesaplarında bir getiri söz konusu olabilmekte fakat özel cari hesapta bu ilişki bir borç doğurmaktadır. Hesap sahipleri tarafindan bu hesaba aktartılan fonlar katılım bankası tarafindan kullanılmaktadır. $\mathrm{Bu}$ işlem sonucunda ortaya çıkabilecek kâr ya da zarardan katılım bankası sorumludur yani bütün risk katılım bankasına aittir (Aktepe, 2010: 72).

\subsubsection{Katılma Hesaplar}

Katılma Hesabı; Özel finans kurumlarına Türk lirası veya yabancı para cinsinden nama yazılı olarak "kâr ve zarara katılma hesabı cüzdanı" karşılığında yatırılan fonların bu kurumlarca kullandırılmasından doğacak kâr veya zarara katılma sonucunu veren, karşılığında hesap sahibine önceden belirlenmiş faiz, kâr ve sair nam altında bir getiri ödenmeyen ve anaparanın aynen geri ödenmesi garanti edilmeyen fonların oluşturduğu hesapları" ifade eder (T.C. Resmî Gazete, 2001).

Katılım bankasına yatırılan tasarruflar karşılığında elde edilen kâr-zarar hesabı gibi vadeli olan hesaplardır. Katılım bankaları, katılım hesapları aracılığı ile yatırımcılarını kâra veya zarara ortak etmektedir. Buradan elde edilen gelir faiz değil, kâr payını ifade etmektedir (Kalayc1, 2013: 12).

Bankacılık kanununda belirtilen katılma hesabı şu şekilde tarif edilir: Katılım bankalarına sağlanan fonların bu kurumlarca kullandırılmasından doğacak kâr veya zarara katılma sonucunu veren, karşıllı̆ında hesap sahibine önceden belirlenmiş herhangi bir getiri ödenmeyen ve anaparanın aynen geri ödenmesi garanti edilmeyen fonların oluşturduğu hesaplara katılma hesabı denir (Aktepe, 2010: 72).

\subsubsection{Birikimli Katılma Hesabı}

Özellikle küçük birikimler ile uzun süreli yatırım yapmak isteyen kişilere yönelik olarak hazırlamıştır. En az 3, en çok 10 yıl vade ile bu hesap açılabilmektedir. Hesaba ödeme yapmak için aylık ya da 3 aylık periyotların beklenmesi gerekmektedir. Hesap açılış işlemlerinden sonra ödeme yapmak için cari hesap kullanılabilmektedir. Ayrıca günümüz koşullarında kredi kartı ile ödeme talimatı da verilebilmektedir. Talimat miktarları güncellenebilmektedir. Hesap açılışı yapıldığı zaman toplu para yatırılabilmektedir. Vadeden önce 3 kere para çekilmesi mümkündür. Fakat hesapta bulunan paranın tümünün çekilmesi mümkün değildir. Yalnızca hesabın yüzde 50'si kadar para çekilebilmektedir. Bu hesapta toplamda beş kez ödeme atlama hakkı bulunmaktadır. Kuralların ihlal edilmesi halinde cezai yaptırım uygulanmaktadır. Buna göre o ana kadar yatırılmış olan bütün brüt kar paylarının yüzde 50'si müşteriden alınmaktadır (albaraka.com.tr).

\subsubsection{Tasarruf Mevduatı}

Fon sahipleri sermayelerini artırmak ve belli bir getiri elde etmek için paralarını yatırmaktadır. Fon sahipleri mevduatlarında bir artış beklemektedir. Faiz haram olduğundan bu artışı kâr veya zarar paylaşımı prensibi ile gerçekleştirmektedir. Bu da kâr veya zarar ortaklığı ile yapılabilmektedir. Ancak hasılatın kâr veya zarar ortaklığına uygun bir şekilde gerçekleştirilmesi gerektiğinden sermaye bu tür bir mevduat için garanti edilememektedir (Schéele, 2002: 25).

\subsubsection{Yatırım Hesabı}

Karma veya Genel Yatırım Hesabında, katılım bankası havuzlarındaki farklı vadelerdeki yatırım mevduatları, belli bir projede kullanılarak yatırım yapılmaz ancak katılım bankasının farklı finansman işlemlerinde kullanılmaktadır. $\mathrm{Bu}$ tip hesabın sahipleri, muhasebeleştirilen ve orantılı 
olarak dağıtılan kârları dönem sonunda almaktadır. Sınırlı Dönem Yatırım Mevduatının temel göstergesi, katılım bankasının belirli bir süre için müşterilerinden mevduat kabul etmesidir. Süresi dolduktan sonra katılım bankası mevduat sahiplerine parasını geri ödemektedir. Bu tür fonlardan elde edilen kârlar mali yılın sonunda dağıtılmaktadır. Sınırsız Dönem Yatırım Mevduatı altında da müşterilerden mevduat kabul edilmektedir. Yatırım mevduatları dönem belirtmeksizin otomatik olarak yenilenebilir niteliktedir. Bu tip hesabın sahipleri, üç ay içinde katılım bankasına bildirerek paralarını çekebilmektedir. Kârlar mali yılın sonunda mevduat sahiplerine dağıtılmaktadır. Ayrıca katılım bankaları, Belirtilmiş Yatırım Mevduatı kabul etmektedir. Burada katılım bankası ve müşteri, belirli bir proje veya ticarette yatırım yapmak için anlaşmaktadır. Bu tip yatırımdan tahakkuk eden kârlar katılım bankası ve müşterileri tarafından paylaşılmaktadır. Bu bağlamda katılım bankası, müşterilerine aracı olarak iş yapar ve yatırımın işlevi için kararlaştırılmış bir ücret talep etmekte ya da üzerinde anlaşılmış bir oranda kâr payı almaktadır (Alam, 2000: 5).

\subsubsection{4. Özel Fon Havuzu}

Katılım bankaları, Kanunun 60'ıncı maddesinin yedinci fikrası uyarınca Türkiye Cumhuriyet Merkez Bankasınca tespit edilen vade ve türlerine bağlı kalmaksızın belirli bir projenin veya yatırımın ya da bu amaçla kurulan ortaklıkların finansmanında kullanılmak üzere müstakil hesaplarda fon toplamak suretiyle vadesi bir aydan daha az olmayan özel fon havuzları oluşturabilir. Hesap sahibi ile katılım bankası arasında düzenlenecek sözleşmede, projenin veya yatırımın içeriğine, öngörülen vadesine ve tarafların hak ve yükümlülüklerine dair hükümlerin yer alması ve projenin veya yatırımın tamamlanmasına kadar geçen süre zarfında katılım bankasının ilgili fon tutarını bu hükümler çerçevesinde kullanması zorunludur. $\mathrm{Bu}$ şekilde toplanan fonlara ait katılma hesapları diğer hesaplardan bağımsız olarak ayrı havuzlarda işletilir ve toplanan fonlar projenin veya yatırımın tamamlanmasına kadar geçen süre zarfında diğer fon havuzlarına aktarılamaz. Özel fon havuzları ile ilgili olarak, oluşturulmasını ve tasfiyesini izleyen on beş gün içinde Kuruma bilgi verilir. Projenin veya yatırımın öngörülen vadesinde veya hesap sahiplerinin onayının alınması ve Kuruma bilgi verilmesi şartıyla projenin veya yatırımın tamamlanmasını müteakip özel fon havuzları tasfiye edilir (T.C. Resmî Gazete, 2018)

Katılım bankaları önceden belli olan yatırımlar veya projeler ve bunların finansmanında kullanmak üzere vadeleri üç aydan az olmamak şartıyla özel fon havuzları yapmaktadır. Burada toplanan fonlar diğer fonlardan ayrı olarak hesaplanmakta diğerlerine herhangi bir aktarım söz konusu olmamaktadır (Güngören, 2013: 37).

\subsection{Katılım Bankacılığı Fon Kullandırma Faaliyetleri}

Para sağlamak katılım bankalarının temel işlevlerindendir. Farklı finansman teknikleri bu imkânları kolaylaştırmak için kullanılmaktadır (Schéele, 2002: 30).

\subsubsection{Kar veya Zarara Ortaklık Esasına Göre Fon Kullanımı}

Katılım bankalarının sıklıkla söz edilen en belirgin özelliği; yapılan işlemlerde kâr veya zarara katılmadır. Kâr/zarar ortaklığı katılım bankacılığının çekirdeği olarak görülmekte ve yaygın olarak İslam hukukçuları tarafindan böyle kabul edilmektedir. Kâr/ zarar ortaklığı finansman yönteminde Mudaraba (kâr paylaşımı) ve Müşareke (ortak girişim) şeklinde iki sözleşme bulunmaktadır (Bitar, 2014: 79).

\subsubsection{Mudaraba (İş Ortaklığı)}

İslami finans sistemi içinde güvenilir ve ilgi gören bir alternatif olarak Mudaraba kâr veya zarar ortaklığı ile finansman sağlamaktadır. Kâr veya zarar paylaşımının temel prensibi, sabit bir oranda geri dönüşü olan borç paranın yerine, borç alan kimseyle bankanın kâr veya zarar paylaşımını benimseyen ortaklık biçimindedir (Kettell, 2011: 25-26).

Mudaraba, bir miktar para yani sermayeyi koyan Rabbul-mal ile deneyimini ve uzmanlığını koyan Mudarib arasında yapılan ticari faaliyet ile belirli bir kâr yüzdesinde anlaşılarak yapılan bir sözleşmedir. Ayrıca Mudaraba'da ticari faaliyet için sermaye sağlayıcı temsilcisinin olması gerektiğini kabul etmektedir. Kâr paylarının oransal olarak sabit olması gerekmektedir. Kârlar yatırımcı sermayesinin geri dönmesinden sonra paylaştırılmaktadır. Yatırımcı tarafından bir kısıtlama 
öngörülmediyse, temsilci yani Mudarib ticari uygulamaya göre ticari faaliyette bulunma konusunda serbest olmaktadır. Ücret karşılığında bir sözleşme olursa bu durumda geçersiz Mudaraba söz konusu olmaktadır. $\mathrm{Bu}$ durumda temsilci bir maaş ile ücretlendirilmekte ve kâr pay1 ödemesi yapılmamaktadır. Sadece temsilcinin işletmede çalışmasından dolayı işletme gideri söz konusudur (Khorshid, 2004: 17).

Mudaraba altında, finansal kayıplar tamamen borç veren tarafından karşılanmaktadır. Böylece girişimci, bir girişimde emeği ve zamanı ile fedakârlık yaptığından ödüllendirilmiş olmaktadır. Finansal kayıptaki bu dağılım ile insan sermayesi ile finansal sermaye eşit olarak ele alınmaktadır (Kettell, 2011: 73).

\subsubsection{Müşareke- Muşaraka (İştirak)}

Kâr ve zarar ortaklığı olarak da nitelendirilen bu fon kullandırma yönteminde iki veya daha fazla kişinin bir araya gelerek, belli miktarlarda sermayeyi birleştirip ortaklık kurmasıdır (Bayındır, 2005: 140). Bu yöntem kâr ve zarar paylaşımına dayanmaktadır. Bu sermaye birleşiminde tarafların her ikisi de kâra ve zarara ortaktır. Kâr paylaşma önceden belirlenen kâr oranı üzerinden yapılırken, zarar edilmesi durumlarında ise sermaye oranı kadar paylaşım yapılmaktadır (Parlakkaya ve Çürük, 2011: 398). Katılım bankaları bu yöntemde, gerçek ve tüzel kişi arasında kâr ve zarar esasına dayanan bir sözleşme imzalamaktadır. Bu sözleşme ile kâra veya zarara hukuki ve mali açıdan güvence sağlanmaktadır (Söyler, 2014: 8).

Katılım bankalarının proje finansmanlarında projeye ortak olma esasına dayanmaktadır. Banka özkaynaklarını veya katılım fonlarını kullanarak yüksek getiri sağlayacak alanlarda yatırımlara ortak olma yoluyla finansman sağlamaktadır. Herhangi bir şekilde proje zarar edecek olursa, bu riski ve proje ortaklarından kaynaklanan problemleri üstlenmek de bankanın sorumluluğunda olmaktadır. Katılım bankaları yatırımlara ortak olduğundan, hem yüksek getiri elde etme imkânı bulmuş hem de ülke iktisadi gelişimine ve istihdama katkı sağlamış olmaktadır (TKBB, 2019: 227).

\subsubsection{Fiyat Artış Esasına Göre Fon Kullanımı}

Perakende fiyat farkı finansmanı İslami finansman yöntemlerinde kâr veya zarar ortaklığı olmayan işlemler olarak da adlandırılmaktadır. Diğer kâr veya zarar araçları ile birleştiğinde, müşterilerin finansal memnuniyetini daha da arttırmaktadır. Ancak perakende fiyat farkı finansman teknikleri İslam hukuku ile uyumlu temel teknikler olarak kabul edilmemektedir. Bu açıklamanın savunucuları, perakende fiyat farkı finansmanını sadece geçici bir önlem olarak ya da kâr veya zarar ortaklığının uygun olmadığı durumlarda kullanılacağını açıklamaktadırlar (Bitar, 2014: 75).

\subsubsection{Murabaha (Vadeli Satış)}

Murabaha, İslami finansta en yoğun kullanılan sözleşmedir. Murabaha katılım bankasının satın almış olduğu çeşitli aktif varlıkların maliyetine yine katılım bankasının kararlaştırdığı kâr marjının eklenmesiyle müşteriye satılan bir satış sözleşmesidir (Tiby, 2011: 47).

Bir Murabaha sözleşmesinde banka, üçüncü bir şahıstan bir varlık veya mal satın almayı kabul eder ve daha sonra malları bir fiyatlandırma ile müşterisine yeniden satar. Müşteri, ürünleri hemen veya ertelenmiş ödeme karşılığında satın alır. Bazı gözlemciler bu İslami finans türünü geleneksel faize dayalı borç verme operasyonuna çok yakın bulmaktadır. Bununla birlikte, Murabaha ile faize dayalı kredilendirme arasındaki önemli bir fark, Murabaha'daki fiyat artışının bankanın sağladığı hizmetler için olması (örneğin, gerekli malları en iyi fiyattan arama ve satın alma) ve fiyatlandırma şartlarında bir zaman aralığı açısından öngörülmemesidir. Bu nedenle, müşteri zamanında bir ödeme yapmazsa, gecikme nedeniyle kâr marjı kararlaştırılan fiyattan artmamaktadır. Ayrıca banka, iki satış arasında malların sahibidir, bu da ilgili riskleri taşıdığı anlamına gelmektedir (Mirakhor ve Hassan, 2007: 52)

Murabaha, kârlı bir satış anlamına gelmekle birlikte aynı zamanda ertelenmiş ödeme satışı anlamına gelmektedir. $\mathrm{Bu}$ bağlamda Murabaha esas olarak taksitli varlık satış sözleşmesidir. Murabaha varlık finansman şeklidir ki bu varlığı katılım bankası satın almakta, daha yüksek bir fiyatla borçluya varlığın satışını yapmaktadır (Kettell, 2011: 38). 
Murabaha işleminde katılım bankası, bir malın satın alınmasında yatırımcıların (mudilerin) temsilcisi olarak hareket etmektedir. Sermaye sahipleri ve yatırımcıların temsilcisi olan İslami banka, malları satın almada ve finanse etmede birtakım riskler ile karşılaşmasına rağmen, banka satın aldığı malı daha sonra son kullanıcıya satmaktadır. Katılım bankasının almış ve satmış olduğu malın fiyatı arasındaki fark önceden belirlenen kâr oranı olarak kabul edilmektedir (Khorshid, 2004: 36).

\subsubsection{2. İcara (Kiralama)}

İcara, İslam fikhında köken olarak Arapça bir terimdir. İcar genel olarak bir şeyi kiralık olarak vermek anlamına gelmektedir. İcara (Leasing), bir varlığın kullanım hakkının kiralayanın (mal sahibi), kiracıya, kira olarak anlaşılmış bir ücretten, kira süresi boyunca devretmesiyle ilgili olan bir sözleşmedir. İcara katılım bankaları tarafından kabul edilen İslami finans yöntemidir. İcara, önemli olan varlıkların ya da ekipmanların finansmanını sağlamak için orta ve uzun vadeli bir finansman tekniğidir. Bu sözleşme kapsamında, müşterinin seçmiş olduğu önemli varlıklar ya da ekipmanlar banka tarafından finanse edilmektedir. Banka bu varlıkları üreticiden veya tedarikçiden satın aldıktan sonra mutabık kalınan süre boyunca müşteriye kiralamaktadır (Kettell, 2011: 38).

İcara, geleneksel bir kiralama gibi belirli bir süre için malların kullanma hakkının satışıdır. Müslüman ülkelerde, kiralama bir ticari faaliyet olarak ortaya çıkmış ve daha sonra bir finans biçimi haline gelmiştir. İcara, bir bankanın müşterisinin ihtiyaç duyduğu bir varlığı veya ekipmanı kira bedeli karşılığında satın aldığı ve kiraladığı bir sözleşmedir. Bakım / sigorta sorumluluğu kiraya verene aittir. Önceden belirlenmiş bir süre boyunca, varlığın mülkiyeti, bakımından sorumlu olan kiraya verene (yani banka) kalmaktadır bu da mülkiyet riskini üstlendiği anlamına gelmektedir. Bir İcara sözleşmesi kapsamında, kiraya veren, anlaşılan aralıklarla kira ödemesi koşullarını yeniden müzakere etme hakkına sahiptir. Bu, kira bedelinin piyasa kiralama oranlarına ve kiralanan varlığın kalıntı değerine uygun kalmasını sağlamak içindir. Bu sözleşmeye göre, kiracının (yani müşterinin) kiralama süresi boyunca veya sonunda varlığı satın alma seçeneği yoktur (Mirakhor ve Hassan, 2007: 52).

\subsubsection{Selem}

Vadeli olan bir malın peşin olarak satmak ya da henüz hazır olmayan vasıflı bir malı peşin olarak bir mal ile değiştirmek olarak tanımlanmaktadır. Bankanın ihtiyacı olan çiftçilere, sermayeden peşin para vererek hasat zamanı teslim alarak mallarını satın alır, teslim aldığı malları piyasaya satarak kazanç elde edilmiş olmaktadır. Böylece çiftçiler faiz karşılığı kredi çekmemekte ve faizli satış yapmamaktadır (Beki 2005: 131).

Satıcının mal bedelini peşin alarak, gelecekte bir tarihte belirli bir malı teslim edeceğini taahhüt ettiği sözleşmedir. Yani ödeme peşin yapılırken teslimat vadelidir. İslam'ın ilk zamanlarında faizin yasaklanması sebebiyle, çiftçiler faizli kredi kullanamamış dolayısıyla finansal kaynak bulamamıştır. Bu sebeple hasat öncesinde tarım ürünlerini peşin olarak satmalarına izin verilmişsir (Kettell, 2011: 117).

\subsubsection{4. İstisna}

Özel ürünlerin üretimi için, genellikle yapı ve inşaat sektöründe kullanılan bir metottur. İstisna, yapılacak veya inşa edilecek bir varlık için, alıcı tarafın taksitlerle ödeme yaptığı bir finansman sözleşmesidir. Örneğin bir feribot şirketinin gemi yapan bir firmaya feribot siparişi vermesi ve feribotun yapım sürecinde bedeli taksitler halinde ödemesi bir istisna örneğidir. Teoride, sözleşme sadece alıcı ve satıcı arasında gerçekleşebilir ancak genellikle iki taraf arasında aracılık rolü üstlenen bir banka sürece dahil olmaktadır. Bankanın yaptığı işlem için aldığı komisyon bankanın kârını oluşturur. Dolayısıyla işlem murabaha ile büyük benzerlik göstermektedir (Kettell, 2011: 103-104).

İstisna, sipariş akdi olan bir fon kullandırma yöntemidir. Bu sözleşme türünde üretilecek olan mal nitelikleri ile sözleşme başında belirlenmektedir. Malın teslim tarihi baştan belli değildir. Mal bedeli taksitlerle de ödenebilmektedir. Bu yöntemin avantajı üretici müşterisini baştan kazanmaktadır (Yanpar, 2015: 98).

İstisna üretim alanında kullanılan İslami bir terim olmakla birlikte inşaat ile ilgili yapıların finansmanında da kullanılmaktadır. Örneğin bir istisna sözleşmesinde müşteri bankaya bir evin inşaatını finanse etmek için müracaat etmektedir. Banka, istenen özellikteki ya da yapıdaki varlıkları 
banka fonları ile finanse etmekte ve müşteri ya da inşaat firmasıyla birlikte evin inşaatını yürütmektedir (Kettell, 2011: 41).

\subsubsection{Karz-ı Hasen (Tüketim Ödüncü)}

Karz-1 Hasen bir toplumda ihtiyaç sahiplerine katılım bankası tarafindan verilen faizsiz kredi anlamına gelmektedir. Uygulamada bu tür yatırımla ilgili olarak bankadan bankaya farklılık görülmektedir. Karz-1 Hasen normalde ihtiyaç sahibi öğrencilere, küçük üreticilere, çiftçilere ve girişimcilere verilmektedir. Bunun yanında kredi alma konumunda olmayan, toplumun ekonomik bakımdan geri kalmış bölgelerine ya da başka herhangi bir kurumsal kaynaktan mali yardım alamayanlara da karşılıksız borç verilmektedir (Alam, 2000: 7).

Karz-1 Hasen uygulamasında, borç alan kimse verilen borca karşılık geri ödeme yükümlülügü altındadır. Bu yükümlülük sözleşme ile yasal hale getirilmiştir. Sözleşmede, geri ödemeye dair belirlenen meblağ, verilen borçtan fazla olamamaktadır. Uygulamada amaç kâr değil, borç alan kişiye yardımdır. Borç verilen kişiden menfaat beklenmemektedir (Yanpar, 2015: 166).

\subsubsection{Sukuk}

İslami finanstaki Sukuk terimi İslami tahvil, katılma belgesi ve varlığa dayalı menkul kıymet anlamına gelmektedir. Bunlar 3 ya da 6 aylık sürelerde olan likit varlıklar olup tahvil gibi ikincil piyasada pazarlanabilen menkul kıymet değildirler. Bu varlıkların rolü klasik borçlanma araçlarıyla birçok benzerlik göstermektedir (Piccinelli, 2010: 32).

Yatırım yapmak isteyen yatırımcıların ihtiyaçlarını karşılamak için biriktirilen tasarruflar ile İslam'a uygun finansal araçları buluşturmanın gereği olarak ortaya çıkmaktadır. İslami finans yönteminde, faize dayalı işlemler ile İslam kanuna uymayan işlemler yapılmamaktadır. Geleneksel Sukuk ile İslami Sukuk arasındaki temel fark, bu araçların yapılandırılması ve piyasaya çıkışı altında olmaktadır. Geleneksel sistemde tahvil ihracatının ve ticaretin özünde tamamen faiz yer almaktadır. Aksine İslami Sukuk'ta belirli bir finansal bedel karşılığında onaylanmış bir varlığın değişimine dayandırılarak yapılandırılmaktadır (Mirakhor ve Zaidi, 2007: 53).

\subsubsection{Joala (Hizmet Akdi)}

Joala yönteminde istisna yöntemine benzeyen yanlar olmakla birlikte bazen birbiriyle karıștırılabilmektedir. İstisna'da satıcı fiziki olarak bir mal sunmakta iken, Joala'da ise satıcı bir mal yerine hizmet sunmaktadır. Bunun dışında diğer yönleri istisnaya benzemektedir. Joala akdinde satıcının sunmak istediği hizmet belirlenirken ayrıca hizmetin fiyatı da belirlenmiş olmaktadır (Yanık ve Sumer 2019: 1181).

\subsubsection{Tavarruk (Teverruk)}

Tavarruk, pek çok İslami finans kuruluşu tarafından kullanılan bir nakit yönetimi tekniğidir. Tavarruk, geçmiş zamanlardan beri bilinip uygulanan bir finansman yöntemi olup bazı mezheplerce ilk zamanlarda bey'ul-ine (alınan malın tekrar aynı satıcıya döndüğü bir işlem) olarak değerlendirilmiş, daha sonraki yıllarda ise müstakil bir sözleşme halini almıştır. Günümüzde ise, operasyonel süreçleri karmaşık, yapılandırılmış ve organize şekilde gerçekleştirilen bir finansal ürün haline gelmiştir (Bayındır, 2015:179).

Tavarruk, ertelenmiş bir ödeme ile bir alıcıya bir varlığın satışının yapılmasıdır. Alıcı daha sonra nakit sağlamak amacıyla ertelenmiş fiyattan daha düşük bir fiyata üçüncü bir tarafa ilgili varlığı peşin olarak satmaktadır. Bununla birlikte bütün Tavarruk işlemi bir borç oluşturmaktadır. Bu borç müşteriye transfer edilen nakitten daha büyüktür. Eğer ödemeler daha sonraki bir tarihte yapılacaksa daha yüksek fiyattan ücret talep etmek fikıh ve hukuk olarak yasal kabul edilmektedir. Fıkıh'a göre, bu faiz talebi anlamına gelmemektedir. Çünkü bu kredi işleminden ziyade ticaret olarak kabul edilmiştir. Ertelenmiş fiyat, peşin fiyattan daha fazla olabilir ancak satış anında sabitlenmektedir. Fiyat sabitlendikten sonra, erken ödeme durumunda fiyatta azalma olmamakta ve temerrüt durumunda da fiyatta artma olmamaktadır. Yani hiçbir şekilde fiyat değişmemektedir (Alkheil, 2012: 12). 


\subsubsection{Komodite}

Nitelik veya kalite olarak herhangi bir farklılık içermeyen emtia mallarının uluslararası piyasalarda anlık ve yüklü miktarlarda alınıp satılması olarak ifade edilmektedir. Tarım ürünleri, altın ve petrol en çok alım satım işlemi gören ürünlerdir. Satıcı ya da alıcı ürünleri görmeden, belirlenen fiyat ve vade farkı ile hazırlanan bir sözleşme yapılarak para transferi yapılmaktadır. En yoğun New York ve Chicago borsalarında komodite işlemleri yoğun olarak gerçekleştirilmektedir. Katılım bankaları kısa süreli likidite dengesizliklerini gidermek amacıyla komodite işlemlerine başvurmaktadır (Öztürk, 2011: 119).

Katılım Bankaları kısa dönemde nakit akışlarını düzenleyebilmek için Komodite'yi tercih edebilmektedir. Aynı zamanda nakit fazlalıklarının değerlendirilmesi için de kullanılan bir yöntemdir. Katılım bankasının talimatıyla paranın yatırıldığı banka katılım bankasının nam ve hesabına Komodite işlemi yaparak, bu işlemlerden elde ettiği kârı katılım bankasıyla paylaşmaktadır (Tunç, 2016: 162).

\subsubsection{Bireysel Finansman Desteği}

Bireylerin ihtiyaç duyduğu mal veya hizmetleri satıcıdan peşin alarak, müşteriye vadeli olarak satmak suretiyle fon kullandırma yöntemidir. Gerçek kişilerin bireysel ihtiyaçlarını karşılamak amacıyla kullanılan bir finansmandır. Ağırlıklı olarak gayrimenkul (ofis, dükkân, arsa ve konut) finasmanında kullanılmaktadır (TKBB, 2019: 179).

Gerçek kişi alıcıların bireysel ihtiyaçlarını karşılamak amacıyla satın aldıkları mal veya hizmet bedelinin, satıcıya katılım bankası tarafından ödenmesi koşuluyla alıcının borçlandırılması işlemidir. Uygulamada, katılım bankaları tarafından kullandırılan bireysel finansman desteği ürünlerini: konut finansman1, kentsel dönüşüm finansmanı, taşıt finansmanı, arsa finansmanı, 2B finansmanı, tüketici (ihtiyaç, dayanıklı tüketim) finansmanı, eğitim finansmanı, hac ve umre finansmanı, bireysel işyeri finansman1, yasa kapsamında ipotekli bireysel finansman, ipotekli bireysel finansman olarak sayılmaktadır (ziraatkatilim.com.tr).

\subsubsection{Kurumsal Finansman Desteği}

Mal veya hizmete ihtiyaç duyan kurumların, satıcıdan peşin alınarak, müşteriye vadeli olarak satılması ile fon kullandırma işlemidir (Murabaha). Kurumsal finansman desteği katılım bankacılığının en yaygın kullanılan finansman türüdür. Reel ekonomik bir faaliyetin finanse edilmesinde önemli rol oynamaktadır. Müşteri finansman için başvurur, kredi değerlemesi yapılır ve uygun olması halinde fon kullandırma limiti tahsis edilmiş olmaktadır. Evrakların tamamlanması ve teminatların alınması ile limit aktif hale getirilir ve müşteri bu limit çerçevesinde kalarak kurumsal finansman desteği işlemlerini yapmış olmaktadır (TKBB, 2019: 178- 179).

Fon talep eden işletme ile katılım bankası arasında düzenlenecek sözleşme kapsamında, işletmenin ihtiyaç duyduğu tüm gayrimenkul, menkul kıymet, emtia, hak ve hizmet bedelinin satıcıya ödenmesi şartı ile işletmenin borçlandırılması işlemidir. Banka borç veren, işletme borçlu, satıcı ise lehtar olarak üçlü bir hukuki ilişki söz konusudur (Çambel, 2017:138).

\subsubsection{Müzaraa}

Müzaraa, bilhassa tarımsal alanda faaliyet gösteren bir ortaklık türüdür. Sermayenin oluşmasında veya tarım arazisinin sahipliği bir kesim (katılım bankası), diğer kesim ise iş gücünü ortaya koymaktadır. Bu yönden mudaraba yöntemine de benzetilmektedir. Yapılan tarımsal çalışma sonucunda elde edilen kar ya da mahsul ortaklar arasında başlangıçta belirlenmiş oran doğrultusunda bölüşülmektedir (Akgüç, 1992: 143).

Müzâraa (ziraat ortaklığı) bir tarafın araziyi diğer tarafın ise emeğini ortaya koyarak zirâî faaliyete ortak olmalarını ifade etmektedir (TKBB, 2019: 225). Bir kişi başkasının mülkiyetinde bulunan toprakları işleyerek, hasat zamanında elde edilen ürünlerin bir kısmının sahibi olma imkânı vermektedir (Tunç, 2010: 134).

\subsubsection{Musakat ve Mugarase}

Musakat, meyve ağaçlarının meyvelerinin paylaşılması için, meyve sahipleri ile bu iş için emek harcayan arasında kurulan ortaklıktır. Bağ ortaklığı, bahçe ortaklığı olarak da bilinmektedir. 
Halk arasında bağını ortağa vermek söylemiyle aynıdır. Sezonda elde edilen ürünler, mal sahibi ile emek sahibi arasında paylaşılmaktadır.

Mugarase de, meyve ağaçları dışındaki çam, kavak gibi ağaçların yetiştirilmesi için, aynı şekilde arazi sahibiyle emek sahibi arasında yapılan ortaklıktır (Serpam, 2013:5).

\subsubsection{Tekafül (Sigorta)}

Tekaful, belirli bir kayıp için tazminat veya diğer türden finansal ihtiyaçlar gibi bir grup birey arasında kararlaştırılan, belirli ihtiyaçları karşılamak, karşılıklı olarak garanti etmek ve birbirlerine yardım etmek için iş birliğini ifade etmektedir. Bu tür bir iş birliği, tüm Tekafül katılımcılarının Tabarru kavramına (gönüllü katkı) dayalı para katkısını içermektedir. Aralarında kararlaştırılan şart ve koşullara uygun olarak herhangi bir katılımcıya parasal yardım kaynağı olarak belirli bir fon oluşturulmaktadır. Karşılıklı yardım (ta'awun) kavramı ve Müslümanların konvansiyonel sigortaya şeriata uygun bir alternatife sahip olma ihtiyacına uygun olarak, Tekafül endüstrisi hızla ulusal finansal sistem de ekonominin ana akımına entegre olan uygulanabilir bir endüstri haline gelmiştir (BNM, 2010: 62).

Şeriata uygun sigorta planlarının düzenlendiği bir risk paylaşımı sistemidir. Şeriat ilkelerine uygun olduğu sürece, bu hizmetlerin kullanımı ile meşru kar ve hizmet bedelleri tahsil edilebilmektedir. $\mathrm{Bu}$ gelirler, kurumun mali sürdürülebilirliğinin temelini oluşturmakta ve sigorta hizmetlerinin devamlılığını sağlamaktadır. (IFSB, 2014: 66).

\section{LITERATÜR TARAMASI}

Katılım bankalarının performanslarına ilişkin literatürde pek çok araştırma bulunmakta olup sonuçlar farkl11ık göstermektedir.

Bashir (2003), 14 katılım bankasının 1993-1998 dönemine ait verileri kullanılarak panel veri analizi uygulamıştır. Bağımlı değişken olarak, özkaynak kârlılığı ve aktif kârlılı̆̆ı, bağımsız değişken olarak makroekonomik faktörler ve içsel faktörleri kullanmıştır. Sonuçta, vergilerin katılım bankaları performans ve kârlılığını olumsuz yönde etkilediğini, pozitif makroekonomik durumların performansı pozitif olarak etkilediğini göstermiştir.

Yudistira (2004), 1997-2000 dönemine ait 18 katılım bankasının etkinliklerini veri zarflama analizi ile ölçerek, 3 girdi (duran varlıklar, toplanan fonlar ve personel giderleri) ve 3 çıktı (kullandırılan fonlar, likit varlıklar ve diğer gelirler) kullanmıştır. Sonuçta; 1997- 1998 yılları arasında genel anlamda pek çok bankanın etkinlik değerinden uzak olduğunu, 1998- 1999 yılları arasında yaşanan kriz döneminden sonra, 1999- 2000 yıllarında ise pek çok bankanın etkin olduğunu analiz sonucunda ortaya koymuştur.

Hassan (2006), 21 ülkenin 43 katılım bankasının verimliliğini parametrik (maliyet ve kârlılık etkinliği) ve parametrik olmayan (veri zarflama analizi) tekniklerle, 1995-2001 dönemi için araştırmıştır. Analiz neticesinde ortalama olarak katılım bankalarının etkinliklerinin düşük olduğunu savunmuştur.

Sufian (2007), 2001-2005 dönemi boyunca Malezya'da faaliyet gösteren katılım bankalarının performanslarını incelemiştir. Veri zarflama analizi ile toplanan fonlar ve takipteki fonlar girdi değişkeni, kullandırılan fonlar ve yatırımlar çıktı değişkeni olarak kullanmıştır. Sonuçta; katılım bankalarının ortalama etkinlik yönünden etkin olmadığını, yabancı katılım bankalarının yerli olan katılım bankalarına oranla daha etkin olduğunu ortaya koymuştur.

Moin (2008), Pakistan'da faaliyet gösteren bir katılım bankasının performansı ile faize dayalı 5 banka grubunun performansını karşılaştırmıştır. 2003-2007 dönemine ait kârlılık, likidite, risk ve etkinlik ile ilgili 12 finansal oran kullanmıştır. İki bankacılık sisteminin performansı arasında bir farklılık olup olmadığını ortaya koymak için T- testi ve F-testi yöntemleri kullanmıştır. Çalışmanın sonuçlarında, katılım bankasının faize dayalı banka grubuna göre daha az kârlı, daha az riskli ve daha az etkin olduğu, buna karşın, likidite açısından bir farklılığın olmadığını ortaya koymuştur.

Parlakkaya ve Çürük (2011) yapmış oldukları çalışmada, finansal özelliklere göre faize dayalı bankalar ve katılım bankaları arasında bir ayrım yapılıp yapılamayacağını belirlemeye çalışmışlardır. 
Model olarak kullanılan Logit analiz de 23 finansal oran yer almıştır. Kullanılan finansal oranlar kârlılık oranları, etkinlik oranları, aktif kalite göstergeleri, likidite oranları ve risk göstergeleri olarak sınıflandırmışlardır. Yapılan araştırma sonucunda, katılım bankalarının faize dayalı bankalardan daha kârlı olduğu, buna karşın faize dayalı bankaların katılım bankalarından daha etkin olduğu ve finansal oranların, katılım bankaları ve faize dayalı bankalar arasında ayırt edici bir fonksiyona sahip oldukları sonucuna ulaşmışlardır.

Omari (2011), Ürdün katılım bankacılığı (JIBFI) ile uluslararası Arap İslam bankasının (IIAB) 2005-2009 dönemine ait etkinliklerini veri zarflama analizi ve rasyo analiz ile ölçmüştür. VZA analizinde toplanan fonlar, duran varlıklar, genel yönetim giderleri ve öz kaynak girdi değişkeni olarak, kullandırılan fonlar ve diğer getirili aktifler çıktı olarak kullanmıştır. Rasyo analizde ise kârlılık oranları, likidite oranları, risk ve ödeme gücü oranlarını kullanmıştır. Yapılan analizin neticesinde, bankaların 2005 ve 2006 yıllarında etkin olmadıklarını, 2009 yılında etkin olduklarını göstermiş̧tir. Yine 2008 y1lında (JIBFI) ve 2007 yılında (IIAB)'nin etkin olduğunu göstermiştir. Rasyo analizde; banka büyüklüğü ve banka yaşının etkili olduğu, her iki grup arasında pek bir farkın olmadığını savunmuştur.

Sufian, Kamarudın ve Noor (2012), 2006-2010 döneminde Malezya'da faaliyette bulunan yerli ve yabancı katılım bankalarının gelir etkinliğini veri zarflama analizi ile incelemişlerdir. Analizde toplanan fonlar ve personel giderleri girdi olarak, kullandırılan fonlar ve gelirleri çıktı olarak kullanmışlardır. Sonuçta; yerli katılım bankalarının yabancı katılım bankalarına kıyasla daha düşük gelir etkinliği gösterdiklerini ortaya koymuşlardır. Dahası katılım bankalarının gelir etkinliği üzerinde işletme sermayesi, pazar gücü ve likidite durumlarının pozitif yönde anlamlı olduğunu göstermişlerdir.

Qureshi ve Shaikh (2012), 2003-2008 döneminde Pakistan'daki ticari bankaların ve katılım bankalarının verimliliklerini finansal rasyo analizi ve veri zarflama analizi ile ölçmüşlerdir. Çalışmalarında; girdi olarak toplanan fonlar ve toplam giderler, çıktı olarak toplam gelirler ve aktif getirisini kullanmışlardır. Ayrıca aktif kârlılığı, özsermaye kârlılı̆̆ı, varlıklara yapılan faiz dışı giderler, mevduata ödenen nakit ve portföy yatırımları, net faiz marjı, gelir masrafı ve varlıklara ilişkin diğer faaliyet gelirlerini finansal rasyo olarak kullanmışlardır. Sonuç olarak; sabit getirili ölçek açısından ticari bankaların daha başarılı olduğunu, rasyo analiz sonucunda ise katılım bankacılı̆̆ının daha az maliyetli ve daha fazla gelir verimliğine sahip olduğunu savunmuşlardır.

Ismail, Shabri, Majid ve Rahim (2013), 2006-2009 döneminde Malezya'daki kat1lım bankalarının ve ticari bankaların maliyet ve teknik etkinliklerini araştırmışlardır. Veri zarflama analizi ve Tobit regresyon analizi kullanmışlardır. Çalışmada personel giderleri, duran varlıklar, toplanan fonlar girdi olarak, kullandırılan fonlar, diğer getirili aktifler ve bilanço dışı yükümlülükleri çıktı olarak kullanmışlardır. Sonuçta; katılım bankacılığının ve ticari bankaların teknik etkinliğinin ana kaynağının ölçek etkinliği olduğunu belirtmişlerdir. Ayrıca katılım bankacılığının maliyet etkinliğinin temel kaynağı olarak dağıtım etkinliği, ticari bankaların maliyet etkinliğinin temel kaynağı olarak, teknik etkinlik olduğunu ifade etmişlerdir. Tobit regresyon analizinin sonucunda ise banka büyüklüklerini pozitif yönde ve anlamlı olarak, verimlilik ile ilişkili ve kredi özellikleri, verimlilik açısından negatif olarak önemli derecede ilişkili olduğunu bulmuşlardır.

Abduh, Hasan ve Pananjung (2013), Bangladeş'de faaliyet gösteren 5 katılım bankasının verimliliklerini ve etkinliklerini veri zarflama ve rasyo analiz ile incelemişlerdir. VZA yönteminde girdi olarak toplanan fonlar, çıtı olarak toplam varlıklar ve toplam finansman gelirini, rasyo analizinde ise kârlılık, kredi riski performansı, yönetim verimliliği ve yönetim becerisi oranlarını kullanmışlardır. Sonuçta; rasyo analizine göre Shajalal Islam Bankasının diğer bankalara göre performansının daha iyi olduğunu göstermişlerdir. Ayrıca bankaların etkinliği açısından bakıldığında bütün bankaların etkinliklerinde iyileşme olduğunu, First Security İslam Bankasının etkinliğinin daha iyi olduğunu göstermişlerdir.

Firdaus ve Hosen (2013), 2010 2. çeyrek- 2012 4. çeyrek dönemlerinde Endonezya'daki katılım bankalarının etkinliğini ölçmek için iki aşamalı veri zarflama analizi ve Tobit Model metodu kullanmışlardır. Girdi olarak toplam varlıklar, personel giderleri ve tüketici fonları, çıktı olarak kâr payı gelirleri ve faaliyet gelirleri değişkeni kullanmışlardır. Sonuçta; katılım bankalarının henüz 
optimum etkinlik düzeyi seviyesine ulaşamadığını, tüm değişkenlerin önemli etkisinin olmadığını ya da bazı değişkenlerin gerçek etkiyi göstermediğini savunmuşlardır.

Ada ve Dalkılıç (2014), 2009-2011 döneminde Malezya ve Türkiye'de faaliyet gösteren katılım bankalarının etkinliklerini ve verimliliklerini ölçmüşlerdir. Çalışmada veri zarflama analizi kullanarak, girdi olarak toplam varlıklar ve toplam öz kaynaklar, çıktı olarak toplam fonlar ve dönem net kârı/zararını kullanmışlardır. Sonuçta; 2009 yılı hariç Türkiye'de faaliyet gösteren katılım bankalarının ölçek etkinliklerinin ortalamasının düşük olduğunu göstermişlerdir. Ayrıca yıllar itibari ile Türkiye'deki katılım bankalarının verimliliklerinin düştügünü, Malezya'daki katılım bankalarının genel olarak verimliliklerinin arttığını göstermişlerdir.

Ayrıçay, Yardımcıoğlu ve Demir (2014), 2006-2011 döneminde Türkiye'de faaliyette bulunan katılım bankalarının ve mevduat bankalarının finansal performanslarını incelemiştir. Çalışmada oran analizi kullanmışlardır. Performansın incelenmesi için likidite oranları, kârlılık ve gelir-gider oranları, verimlilik oranları ile risk ve sermaye yeterlilik oranlarını kullanarak, likidite yeterliliği bakımından katılım bankalarının mevduat bankalarına göre daha iyi bir düzeyde olduğu sonucuna varmışlardır. Katılım bankalarının daha az riskli olduklarını ifade etmişlerdir. Verimlilik oranları bakımından ise, katılım bankalarının mevduat bankalarına oranla daha fazla artış gösterdiğini ortaya koymuşlardır.

Gümüş ve Nalbantoğlu (2015), Türkiye'de faaliyet gösteren Kamu, Yerli Özel, Yabancı ve Katılım Bankalarının 2002-2013 yılları arasındaki performansını CAMELS analiz yöntemiyle karşılaştırmalı olarak değerlendirmişlerdir. Performans ölçümünde sermaye yeterliliği, aktif kalitesi, yönetim kalitesi, kârlılık, likidite ve piyasa riskine duyarlılık değişkenleri kullanmışlardır. Sonuç olarak, yerli özel sermayeli bankaların yönetim kalitesi ve kârlılıkta göstermiş oldukları olumlu performanstan dolayı en yüksek puana sahip olduklarını belirtmişlerdir. Katılım bankalarının faizsiz enstrümanlar kullanım zorunluğu ve sermayelerinin banka gruplarına nispeten zayıf kalması nedeniyle performansının düşük olduğunu belirtmişlerdir. Fakat piyasa riskine duyarlılıkta ise katılım bankalarının ve yabancı bankaların başarılı bir bilanço yönettiklerini göstermişlerdir.

Toraman, Ata ve Buğan (2015), mevduat ve katılım bankalarının, 2006-2014 yılları arasındaki finansal oranlardan yararlanarak karşılaştırmalı performanslarını incelemişlerdir. Analizde dinamik panel veri analizi ve t-testini kullanmış olup bağımlı değişken olarak, aktif kârlılığı, bağımsız değişkenler olarak, aktif büyüklüğü, likidite, operasyonel etkinlik, sermaye yeterliliği ve kredi kalitesini kullanmışlardır. Sonuçta; t-testinde, katılım bankalarının toplam aktif ve likit aktif büyüklüklerin mevduat bankalarından daha düşük olduğunu, sermaye yeterliliği bakımından ise mevduat bankalarının katılım bankalarına göre daha güçlü bir yapıda olduğunu göstermişlerdir. Panel veri analiz sonucunda aktif büyüklüğü ile aktif kârlılığı arasında pozitif yönde bir ilişki bulunmuş fakat istatistiksel olarak anlamlı olmadığını ve likidite ile de anlamlı bir ilişki bulunmadığını göstermiş̧lerdir. Operasyonel etkinliği temsil eden net faiz marjı ile aktif kârlılığı arasında pozitif yönlü ve $\% 5$ seviyesinde anlamlı bir ilişki tespit etmişlerdir. Kredi kalitesi göstergesi olarak kullanılan oran ile aktif kârlılığı arasında beklenildiği gibi negatif ve \%1 seviyesinde anlamlı bir ilişki ve sermaye yeterliliğinin göstergesi olan oran ile aktif kârlılığı arasında pozitif yönlü ve $\% 5$ seviyesinde anlamlı bir ilişki bulmuşlardır.

Doğan (2015), Gri İlişkisel Analiz (GİA) yöntemini kullanarak 2012-2014 yılları arasında Türkiye'de faaliyet gösteren katılım bankalarının finansal performans karşılaştırılmasını yapmıştır. Veri olarak sermaye yeterliliği, kârlılık, likidite, bilanço yapısı ve aktif yapısı değişkenlerini kullanmıştır. Analiz sonucunda, Albaraka Türk'ün finansal performansının en yüksek Bank Asya'nın ise en düşük olduğunu göstermiştir. Ayrıca, varlık kârlılığı yüksek olan bir katılım bankasının finansal performansının da yüksek olabileceğini vurgulamıştır.

Görüş ve Özgür (2016), banka içi faktörlerin Türkiye'deki katılım bankalarının kârlılıkları üzerindeki etkilerinin tahmin edilebilmesini amaçlamışlardır. 2006 yılı birinci ay ve 2016 y1lı ikinci ay dönemleri arası aylık verilerini kullanmışlardır. Türkiye'deki beş katılım bankası olan, Albaraka Türk, Bank Asya, Kuveyt Türk, Türkiye Finans ve Ziraat Katılım Bankalarının toplulaştırılmış verilerini kullanmışlardır. Bağımlı değişken olarak aktif kârlılığı (ROA) bağımsız değişken olarak öz sermayenin toplam varlıklara oranı (ETA), kredi kalitesi (LQ), kredilerin toplam varlıklara oranı (LTA), net faiz marj1 (NIM), faaliyet giderlerinin toplam varlıklara oranı (OETA), pazar pay1 (MS), ve 
faiz dışı gelirin toplam varlıklara oranı (NII) kullanmışlardır. Analiz sonuçlarına göre, ETA, NIM ve MS'nin aktif kârlılığı üzerindeki etkilerini pozitif ve anlamlı bulmuşlardır.

Kevser (2021), yaptığı çalışmada, Türk bankacılık sektöründe faaliyette bulunan 12 adet bankanın 2013-2018 dönemi, finansal performansını karşılaştırmalı olarak analiz etmiştir. Araştırmada sermaye yeterlilik, kârlılık, aktif kalitesi, likidite ve gelir-gider yapısı oranlarından oluşan 13 adet finansal oran kullanarak kamu bankalarının, özel bankaların, yabancı bankaların ve katılım bankalarının finansal performansını ölçmüştür. Sonuçlara göre, sermaye yeterliliğinde özel bankaların, kârlılıkta kamu bankalarının daha iyi performans sergilediği, katılım bankalarının takipteki net kredilerinin toplam aktiflere oranını yüksek, aynı zamanda TP likit aktiflerinin toplam aktiflere oranını ise düşük bulmuştur. Net faiz gelirlerinin toplam aktiflere oranında ise en başarılı performansı yabancı bankaların gösterdiğini savunmuştur.

\section{TÜRKIYE'DE FAALIYET GÖSTEREN ALTI KATILIM BANKASI İÇIN ORAN ANALIZI KULLANILARAK PERFORMANSLARININ KARŞILAŞTIRILMASINA YÖNELIKK BİR UYGULAMA}

Literatür incelendiğinde katılım bankaları, mevduat ya da diğer banka türleri ile karşılaştırılmasının çoğunlukta olduğu görülmüştür. Ülkemizde halen faaliyette bulunan altı katılım bankasının (Albaraka Türk Katılım Bankası, Kuveyt Türk Katılım Bankası, Türkiye Finans Katılım Bankas1, Ziraat Katı1ım Bankası, Vakıf Katılım Bankası ve Türkiye Emlak Katılım Bankası) birbirleri arasında bir performans kıyaslamasının yapılacağı bu çalışma ile literatüre katkı sağlayacağı düşünülmüştür. Bu sebeple çalışmada kullanılan oranlar hakkında kısaca bilgi verilmiştir:

Oran analizinde özellikle finansal analizlerde büyük ölçüde yararlanılmaktadır. Mali tablolarda yer alan iki kalem arasındaki basit ilişkilerin matematiksel olarak ifade edilebilmesi açısından önemlidir. Finansal değerlendirmelerde oran analizi yapılırken, oranların teker teker karşılaştırılması yapılır (Başkaya ve Avc1, 2011: 84).

Mali tabloların analizinde yaygın olarak kullanılan tekniklerden biri oran analizi yöntemidir. Oranlar mali tablolar içinde yer alan iki kalem arasındaki ilişkinin matematiksel olarak ifadesidir (Çabuk ve Lazol, 2012: 199).

$\mathrm{Bu}$ analaliz tekniğinde finansal tablolardaki kalemler arasındaki anlamlı ilişkiler birbirinin yüzdesi veya katı olarak belirtilmektedir. Rasyo yöntemi ile analiz olarak da adlandırılan bu yöntemde hesap veya hesap grupları arasında matematiksel ilişki kurularak işletmenin mali, ekonomik yapısı, karlılık ve çalışma durumu hakkında bilgi edinilmeye çalışılmaktadır (Akdoğan ve Tenker, 2007: 640)

Oranlar, geniş anlamda iki sayı arasındaki ilişkiyi göstermektedir. Mali analizler bakımından oranlar bilanço ve gelir tablolarında yer alan kalemler arasında ilişkilendirilmektedir. Tek başına fazla bir anlam belirtmeyen hesap grupları ve mali tablolara ilişkin kalemler oranlar yoluyla daha da anlamlı hale gelmektedir (Yalkın, 1981: 100). Oranlar ve yüzdeler, analistlere geleceğe yönelik tahminlerde bulunma konusunda yardımcı olmaktadır. Kredi veren kurumlara işletmenin vadesi gelmiş mali yükümlülüklerini karşılayabileceği konusunda bilgiler verip, ortaklara yaptıkları yatırımlarda belirli bir artış olup olmadığını göstermektedir. Sonuç olarak, işletmelerin mali yapılarını açıklamaktadır (Çetiner, 2000: 138).

Sermaye Yeterlilik Oranları: Bu oran, banka sermayesinin toplam pozisyonuna odaklanır ve mevduat sahiplerinin bir bankanın maruz kaldığı olası kayıplardan korur (Nimalathasan, 2008: 142). Bankacılık kanununda risklere maruz kalınması sebebiyle ortaya çıkabilecek zararlara karşı yeterli seviyede kaynak bulundurulmas1 sermaye yeterliliğini belirtmektedir (Akgüç, 2012: 459). Sermaye yeterliliği, bankaların finansal gücünün ölçülmesini ifade etmektedir. Sermaye yeterliliği standart oranı, bankaların görevlerinin yerine getirilmesi, piyasa, kredi ve operasyonel risk gibi risklere karş1 kapasitesini tespit eden orandır. Sermaye yeterliliği oranı, bankaların risk oluşturan varlıklarına destek olmak amacıyla ne kadar sermayeye sahip olunması gerektiğinin ölçüsünü belirtmektedir. Bankalar faaliyetlerini devam ettirebilmeleri ve büyüme göstermeleri için sermaye kaynaklarını verimli olarak kullanmaları gerekmektedir. Sermaye yeterliliği oranı, bankaların finansal başarısızlıkları ile negatif bir ilişkiye sahip olup, finansal güvenilirlikleri açısından pozitif bir ilişkisi söz konusudur. $\mathrm{Bu}$ bakımdan bankanın sermaye yeterlilik oranının yüksek olması veya sermaye yapısındaki gücü, olası 
risklere karşı finansal sisteminin güçlülügünün ve muhtemel finansal başarısızlık riskinin düşük olduğunun belirtisidir. Bankaların yeterli seviyede sermayeye sahip olması bankaların devamlılığ açısından önem taşımaktadır (Güney ve Ilgın, 2016: 307).

Aktif Kalitesi Oranları: Bankacılıkta aktif değerlerin azalması sonucu belirli bir risk oluşturmaktadır. Bankacılık sektöründe, bankalara faiz yükü oluşturan yabancı kaynakların toplam banka kaynaklarının önemli bir bölümünü oluşturmaktadır. Dolayısıyla öz kaynak payının daha az olmas1, pasiflerin esnekliğini düşürmektedir (Akgüç, 2012: 521). Aktif kalitesi ile bankaların varlık kalitesi incelenmektedir. Bilanço işlemlerinin haricinde yatırım portföyleri ve kredi risklerinin beraberinde getirdiği potansiyel ve mevcut kredi riskini, sahip olunan gayrimenkuller ve diğer varlıkların kalitesini göstermektedir. Yönetimin kredi risklerini ölçme, tanımlama, kontrol etme ve izleme yeteneği de bu bileşen içinde değerlendirilmektedir (Sakarya, 2010: 14). Aktif kalitesi, bankaların varlıklarının risk seviyesini ve mali gücünün oranını belirtmektedir. Bunun yanında bu bileşen, bankaların mevcut durumunu ve gelecek zamandaki finansal kapasitesinin değerlendirilmesinde önemlidir. Bankaların aktif kalemler içindeki kredilerin payının fazlalığından dolayı aktif kalitesini değerlendirmek için kullanılan kriterlerin birçoğu kredilerin kalitelerinin ölçülmesinde kullanılmaktadır (Güney ve Ilgın, 2016: 307).

Yönetim Kalitesi Oranları: Yönetim, bankanın düzgün işleyişinin riskleri ele almasını ve yönetimi kalitesini kontrol altına almasını sağlayacak kararları veren mekanizmayı oluşturmaktadır. Yönetimin kalitesi doğru yönetim ve sorunsuz işleyiş için önemlidir (Christopoulos, Mylonakis ve Diktapanidis, 2011: 12). Yönetim kalitesi, yönetimsel performans ve kapasiteyi ifade etmektedir. Bu bileşenin yardımıyla yönetim ve yönetim kurulu kendi görev ve sorumluklarıyla ilgili olarak kurumun faaliyetlerine ilişkin riskleri ölçme, izleme, tanımlama, kontrol etme ve kurumun yasa ve yönetmeliklere uygun olarak verimli ve güvenli çalışmasını sağlayabilme kapasitesi tespit edilmektedir (Çă̆ıl ve Mukhtarov, 2014: 84). Bankalarda yönetim kalitesi yalnız mali performanslara bağlı değildir. Yönetim kalitesi, yönetim uzmanlığı ve eğitim derecesi konuları gibi geniş bir alanı olan bileşendir. $\mathrm{Bu}$ sebeple, bu bileşeni başka bileşenlerle karşılaştırılması yapıldığında, değerlendirilmesi ve ölçümü en zor olan bileşendir. Diğer bileşenler mali tablolardan kolayca elde edilebilirken, yönetim kalitesi bileşeninin somut verilerle sağlanmasında zorluk yaşanmaktadır. Bankalarda yönetim kalitesi, günlük operasyonel faaliyetlerin devam ettirilmesi, kârlılığın elde edilmesi, mevduat sahiplerinin haklarının dikkate alınması, bankacılık sistemindeki kanunlara ve düzenlemelere uygun olarak güvenilir ve verimli bir biçimde faaliyetlerini devam ettirebilmeleri ile değerlendirilebilmektedir. Bankaların yönetim konusundaki kapasitesini belirten bu bileşen, bankaların faaliyetleri sonucunda meydan gelen riskleri ölçme, tespit etme ve kontrol etmede bankaların rollerini ve yeteneklerini göstermektedir (Güney ve Ilgın, 2016: 308).

Kârlıık Oranları: Kârlılık oranlarının hesaplanması için genelde gelir tablosu kalemleri bilanço kalemlerine bölünerek belirlenmektedir. Gelir tablolarının dönemsel dinamik bir tablo olmasına karşın, bilançonun da belirli bir zamandaki durumlarını belirten statik bir tablo olması karşılaştırmaları anlamsız hale getirmektedir. Bu bakımdan karşılaştırmaların daha anlamlı hale gelebilmesi için bilançonun da gelir tablosunda olduğu gibi dönemsel durumuna getirilerek kalemlerin dönemsel ortalamaları kullanılması gerekli görülmektedir (Akgüç, 2012: 532). Bir bankanın güçlü kârlılık ve gelir profili, mevcut ve gelecekteki operasyonları destekleme yeteneğini yansıtmaktadır. Yani bu durum yeterli bir sermaye tabanı oluşturarak, genişlemeyi finanse ederek ve hissedarlarına yeterli temettü ödeyerek kayıplarını karşılayacak kapasiteyi belirler (Nimalathasan, 2008: 142). Kazançlardaki kalitenin azalmasına, olağanüstü kazançlara olan fazla bağımlılık, beklenmeyen olaylar ve verimli olmayan vergi etkisi gibi konular sebep olmaktadır (Çağıl ve Mukhtarov, 2014: 82).

Likidite Oranları: Likidite değerlendirmesinde, bankanın mevcut likidite durumu, üstlendiği yükümlülüklere göre dikkate alınmaktadır. Aynı zamanda bankanın finansman kaynaklarındaki değişikliklerle uğraşma becerisini ve varlıklarının hızlı bir şekilde tasfiyesini gerçekleştiren piyasa koşullarındaki değişiklikleri mümkün olan en az zararla test etmektedir (Christopoulos vd., 2011: 13). Bankacılık sektöründe likidite, talep edilmiş fonları normal maliyetlerle karşılamaktadır. Likidite yönetiminde iki önemli husus vardır. Bunlardan birincisi bankanın devamlı likidite fazlası veya açı̆̆ı olmasıdır. Bu durum likidite arzı ve talebinin birbirlerine eşit olmamasıyla ifade edilmektedir. Genellikle mevduat bankalarında, likidite talepleri kolaylıkla karşılanabilmesi için kaynaklar en likid 
varlıklara bağlanmaktadır. Bu durum bankaların kârlılığını negatif yönde etkilemektedir. Tersi bir durum söz konusu ise bankalar fon taleplerini daha yüksek maliyetli karşılamak zorunda kalacaklardır. Dolayısıyla bankalar likidite ve kârlılık arasında dengeyi sağlamaları gerekecektir. Bu bileşen bankaların likidite hareketlerini incelemek ve ölçmek için kullanılmaktadır (Aytekin ve Sakarya, 2013: 36).

Piyasa Riskine Duyarlılık Oranları: Duyarlılık, piyasa riskini esas olarak, emtia fiyatındaki, faiz oranlarındaki, döviz kurundaki, sabit varlıklardaki olumsuz değişimlere ve yönetimin bu riskleri belirleme ve kontrol etme yeteneğine dayalı olarak değerlendirmektir (Babar ve Zeb, 2011: 24). Bu bileşen ile bankanın mal fiyatlarında, faiz oranlarında, hisse senedi fiyatlarında, kurlardaki değişimlerin neden olduğu piyasa riskine duyarll1ı̆̆1 incelenmektedir (Türker Kaya, 2001: 5). Bankaların sermayesinde ya da kazançlarında olumsuz etkiye neden olabilecek, kurlarda, hisse senedi fiyatlarında, mal fiyatlarında ve faiz oranlarındaki değişimlerden kaynaklanan piyasa riskine duyarlılı̆̆ ifade etmektedir. Bu bileşen değerlendirildiğinde yönetimin piyasa risklerini ölçme, tespit etme, kontrol etme ve izleme becerisi, kurum faaliyetlerin türü, büyüklüğü, karmaşıklığı ve maruz kalınan piyasa riskleri derecesiyle bağlantılı olarak sermaye kazançları ve yeterliliğinin dikkate alınması gerekliliği söz konusudur (Çağıl ve Mukhtarov, 2014: 82).

\subsection{Araştırmanın Amacı}

Türkiye'de faaliyet gösteren Albaraka Türk Katılım Bankası, Kuveyt Türk Katılım Bankası, Türkiye Finans Katılım Bankası, Ziraat Katılım Bankası, Vakıf Katılım Bankası ve Türkiye Emlak Katılım Bankası olmak üzere, altı katılım bankasının 01 Ocak 2019- 31 Aralık 2019 hesap dönemine ait konsolide finansal tablolar ve bağımsız denetim raporları ile konsolide kar/ zarar tabloları kullanılarak, sermaye yeterlilik, aktif kalitesi, yönetim kalitesi, kârlılık, likidite ve piyasa riskine duyarlılık oranlarının hesaplanması ile verilerin karşılaştırılması yapılarak, bankaların oranlar bazında performanslarının değerlendirilmesi yapılarak, literatüre katkısı amaçlanmıştır.

\subsection{Veri Seti ve Örneklem}

Türkiye Katılım Bankaları Birliği'nin resmî web sitesinden ve Albaraka Türk Katılım Bankası, Kuveyt Türk Katılım Bankası, Türkiye Finans Katılım Bankası, Ziraat Katılım Bankası, Vakıf Katılım Bankası ve Türkiye Emlak Katılım Bankası'nın resmî web sitesinden analiz için gerekli finansal tablolar ve bağımsız denetim raporları ile konsolide kar/ zarar tablolarında yer alan veriler kullanılmıştır.

Türkiye'de halen mevcut, altı (6) katılım bankasının 2019 yılı verileri kullanılarak, otuz sekiz (38) oranın (Tablo 2) hesaplaması yapılmıştır. Hesaplanan bu oran değerleri ve ortalamalar Tablo 3 'te gösterilmiştir.

\subsection{Kapsam ve Sinırlılıklar}

Analiz sonucunda elde edilen bulguların yanı sira birtakım kısitlamalar da mevcuttur. Bankacılık sektöründe faaliyet gösteren altı (6) katılım bankasının dahil edilmiş olması ve 2019 yılı faaliyet dönemine ait verilerin incelenmesi temel kısıtları oluşturmaktadır. Gelecekte yapılacak çalışmalarda daha fazla banka ve finansal oran sayısının arttırılması ile yazın güçlendirilebilir.

\subsection{Araştırmanın Yöntemi}

Çalışmada, katılım bankalarının finansal ve yönetsel performans değerlendirme oranlarını içeren altı bileşenden oluşan oranlardan faydalanılarak, oran analizi yöntemi ile performansları değerlendirilmiştir. Bankaların performans değerlendirmelerinde sermaye yapısı, aktif kalitesi, yönetim yeterliliği, karlılık durumu, likidite ve piyasa risk oranları göz önünde bulundurulmuştur.

Öncelikle oranlar tablo haline getirilerek, kolaylık olması amaciyla, oran kodları oluşturulmuştur. Aşağıda oranlar ve kodları gösterilmiştir. 
Katılım Bankalarına Genel Bakışv ve Geleneksel Performans Değerleme Yöntemi Olarak Oran Analizi Uygulaması

Tablo 2. Performans Oranları ve Oran Kodları

\begin{tabular}{|c|c|}
\hline PERFORMANS ORANLARI & $\begin{array}{c}\text { Oran } \\
\text { Kodu }\end{array}$ \\
\hline \multicolumn{2}{|l|}{ SERMAYE YETERLİLIK ORANLARI } \\
\hline 1- ÖZKAYNAKLAR/ TOPLAM AKTİFLER & $\mathrm{S} 1$ \\
\hline 2- (ÖZKAYNAKLAR- DURAN AKTİFLER)/ TOPLAM AKTİFLER & $\mathrm{S} 2$ \\
\hline 3- ÖZKAYNAKLAR/ (MEVDUAT+ MEVDUAT DIŞI KAYNAKLAR) & S3 \\
\hline 4- NET DÖNEM KARI/ TOPLAM AKTİFLER & S4 \\
\hline 5- NET ÇALIŞMA SERMAYESİ/ TOPLAM AKTİFLER & S5 \\
\hline \multicolumn{2}{|l|}{ AKTİF KALITESI ORANLARI } \\
\hline 1- DURAN AKTİFLER/ TOPLAM AKTİFLER & $\overline{\mathrm{A} 1}$ \\
\hline 2- FINANSAL VARLIKLAR NET/ TOPLAM AKTİFLER & $\mathrm{A} 2$ \\
\hline 3- TOPLAM VERİLEN KREDİLER/ TOPLAM MEVDUAT & A3 \\
\hline 4- TOPLAM VERİLEN KREDİLER/ TOPLAM AKTİFLER & A4 \\
\hline 5- TOPLAM KREDİLER VE ALACAKLAR/ TOPLAM AKTİFLER & $\overline{\mathrm{A} 5}$ \\
\hline 6- TOPLAM KREDİLER VE ALACAKLAR/ TOPLAM MEVDUAT & A6 \\
\hline 7- TOPLAM ALINAN KREDİLER/ TOPLAM PASİFLER & A7 \\
\hline \multicolumn{2}{|l|}{ YÖNETIMM YETERLILLIĞİ ORANLARI } \\
\hline 1- ŞUBE BAŞINA NET KAR= NET KAR/ ŞUBE SAYISI & $\mathrm{Y} 1$ \\
\hline 2- DİĞER FAALIYYET GİDERLERİ/ TOPLAM AKTİFLER & Y2 \\
\hline 3- TOPLAM FAALIYYET GELİRLERİ NET/ TOPLAM AKTİFLER & Y3 \\
\hline 4- (PERSONEL GİDERLERİ+ KIDEM TAZMINATI)/ TOPLAM AKTİFLER & Y4 \\
\hline 5-KAR PAYI DIŞI GELİRLER NET/ TOPLAM AKTİFLER & Y5 \\
\hline 6- KAR PAYI DIŞI GELİRLER NET/ DİĞER FAALIYYET GİDERLERİ & Y6 \\
\hline \multicolumn{2}{|l|}{ KARLILIK ORANLARI } \\
\hline 1- NET DÖNEM KARI (ZARARI)/ ÖZKAYNAKLAR & K1 \\
\hline 2- NET DÖNEM KARI (ZARARI)/ TOPLAM AKTIFFLER & $\mathrm{K} 2$ \\
\hline 3- NET DÖNEM KARI (ZARARI)/ ÖDENMISS SERMAYE & K3 \\
\hline 4- TOPLAM GELİRLER/ TOPLAM GİDERLER & K4 \\
\hline 5- ÖZEL KARŞILIKLAR SONRASI NET KAR PAYI GELİRLERİ/ TOPLAM AKTİFLER & K5 \\
\hline 6- KAR PAYI GELİRLERİ/ KAR PAYI GİDERLERİ & K6 \\
\hline 7- KAR PAYI DIŞI GELİRLER/ KAR PAYI DIŞI GİDERLER & K7 \\
\hline 8- VERGİ ÖNCESİ KAR/ TOPLAM AKTİFLER & K8 \\
\hline \multicolumn{2}{|l|}{ LİKİDITE ORANLARI } \\
\hline 1- LIKİT AKTIFFLER/ TOPLAM AKTİFLER & L1 \\
\hline 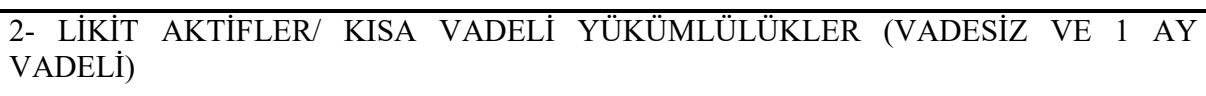 & $\mathrm{L} 2$ \\
\hline 3- LIKİT AKTİFLER/ MEVDUAT+ MEVDUAT DIŞI KAYNAKLAR & L3 \\
\hline 4- TP LIKİT AKTİFLER/ TOPLAM AKTİFLER & L4 \\
\hline 5- YP LİKİT AKTİFLER/ YP PASİFLER & $\overline{\mathrm{L} 5}$ \\
\hline
\end{tabular}




\begin{tabular}{|l|c|} 
PIYASA RISKINE DUYARLILIK ORANLARI & \\
\hline 1- KAR PAYI GELIRLERİ/ TOPLAM AKTIFLER & P1 \\
\hline 2- YP AKTIFLER/ YP PASİFLER & P2 \\
\hline 3- YP AKTİFLER/ TOPLAM AKTIFLER & P3 \\
\hline 4- TP AKTİFLER/ TOPLAM AKTİFLER & P4 \\
\hline 5- TP KREDİLER VE ALACAKLAR/ TOPLAM KREDİLER VE ALACAKLAR & P5 \\
\hline 6- KAR PAYI GİDERLERİ/ TOPLAM GIDERLER & P6 \\
\hline 7- KAR PAYI DIŞI GELİLLER / TOPLAM AKTIFLER & P7 \\
\hline
\end{tabular}

Ardından, 01 Ocak 2019- 31 Aralık 2019 hesap dönemine ait konsolide finansal tablolar ve bağımsız denetim raporları ile konsolide kar/ zarar tabloları kullanılarak altı bileşenden oluşan oranların hesaplanması yapılmıştır.

Tablo 2'de, performans oranlarının her banka için ayrı ayrı hesaplanmasından sonra;

Banka bazında S kodlu oranların ortalaması hesaplanmıştır. Bankaların S oranları ortalamaları kullanılarak, S oran ortalaması sonucuna ulaşılmıştır.

Banka bazında A kodlu oranların ortalaması hesaplanmıştır. Bankaların A oranları ortalamaları kullanılarak, A oran ortalaması sonucuna ulaşılmıştır.

Banka bazında Y kodlu oranların ortalaması hesaplanmıştır. Bankaların Y oranları ortalamaları kullanılarak, Y oran ortalaması sonucuna ulaşı1lmıştır.

Banka bazında $\mathrm{K}$ kodlu oranların ortalaması hesaplanmıştır. Bankaların $\mathrm{K}$ oranları ortalamaları kullanılarak, K oran ortalaması sonucuna ulaşılmıştır.

Banka bazında L kodlu oranların ortalaması hesaplanmıştır. Bankaların L oranları ortalamaları kullanılarak, L oran ortalaması sonucuna ulaşılmıştır.

Banka bazında P kodlu oranların ortalaması hesaplanmıştır. Bankaların P oranları ortalamaları kullanılarak, P oran ortalaması sonucuna ulaşılmıştır.

Oran ortalaması üzerinde kalan banka ortalamasının performansının istendik ve iyi, ortalamanın altında kalan banka ortalamasının istenilmeyen yani düşük olduğu ifade edilmektedir.

Aşağıdaki Tablo 3'te; Tablo 2'de yer alan oranların her banka için ayrı ayrı hesaplaması yapılmıştır (örneğin S1, S2, ..., S5). Ardından her banka için banka oran ortalaması bulunmuştur. Banka oran ortalamalarının aritmetik ortalaması ile oran ortalaması sonucuna ulaşılmıştır (örneğin $\mathrm{S}$ oran ortalaması). Tüm işlemler her oran kodu için hesaplanmıştır.

Tablo 3. Oran Değerleri ve Ortalamalar

\begin{tabular}{|l|l|l|l|l|l|l|l|}
\hline $\begin{array}{l}\text { Oran } \\
\text { Kodu }\end{array}$ & $\begin{array}{l}\text { Albaraka } \\
\text { Türk } \\
\text { Kat1lım }\end{array}$ & $\begin{array}{l}\text { Kuveyt Türk } \\
\text { Kat1lım }\end{array}$ & $\begin{array}{l}\text { Türkiye } \\
\text { Finans } \\
\text { kat1lım }\end{array}$ & $\begin{array}{l}\text { Vakıf } \\
\text { Kat1lım }\end{array}$ & $\begin{array}{l}\text { Ziraat } \\
\text { Kat1lım }\end{array}$ & $\begin{array}{l}\text { Emlak } \\
\text { Kat1lım }\end{array}$ & $\begin{array}{l}\text { S Oran } \\
\text { Ortalamas1 }\end{array}$ \\
\hline S1 & 0,0783 & 0,06351 & 0,0927 & 0,0647 & 0,0870 & 0,1260 \\
\hline S2 & $-0,0032$ & 0,02881 & 0,0386 & 0,0386 & 0,0695 & 0,0717 \\
\hline S3 & 0,0904 & 0,07111 & 0,1089 & 0,0717 & 0,0992 & 0,1679 \\
\hline S4 & 0,0019 & 0,01049 & 0,0072 & 0,0107 & 0,0142 & 0,0048 \\
\hline S5 & 0,0524 & 0,07221 & 0,0951 & 0,0709 & 0,1049 & 0,1956 & \\
\hline $\begin{array}{l}\text { Banka } \\
\begin{array}{l}\text { Oran } \\
\text { Ortalamas1 }\end{array}\end{array}$ & $\mathbf{0 , 0 4 4 0}$ & $\mathbf{0 , 0 4 9 2}$ & $\mathbf{0 , 0 6 8 5}$ & $\mathbf{0 , 0 5 1 3}$ & $\mathbf{0 , 0 7 5 0}$ & $\mathbf{0 , 1 1 3 2}$ & $\mathbf{0 , 0 6 6 9}$ \\
\hline $\begin{array}{l}\text { Oran } \\
\text { Kodu }\end{array}$ & & & & & & & $\begin{array}{l}\text { A Oran } \\
\text { Ortalamas1 }\end{array}$ \\
\hline
\end{tabular}


Katılım Bankalarına Genel Bakışve Geleneksel Performans Değerleme Yöntemi Olarak Oran Analizi Uygulamast

\begin{tabular}{|c|c|c|c|c|c|c|c|}
\hline A1 & 0,0816 & 0,0347 & 0,0541 & 0,0261 & 0,0175 & 0,0543 & \\
\hline $\mathrm{A} 2$ & 0,3018 & 0,4059 & 0,3381 & 0,3534 & 0,1708 & 0,2101 & \\
\hline A3 & 0,7710 & 0,6488 & 0,8175 & 0,8099 & 1,0177 & 0,9627 & \\
\hline A4 & 0,5952 & 0,5358 & 0,6261 & 0,6128 & 0,7119 & 0,6173 & \\
\hline A5 & 0,6167 & 0,5594 & 0,6078 & 0,6205 & 0,8117 & 0,7356 & \\
\hline A6 & 0,7988 & 0,6774 & 0,7936 & 0,8201 & 1,1603 & 1,1470 & \\
\hline A7 & 0,0267 & 0,0316 & 0,0287 & 0,0177 & 0,0233 & 0,1160 & \\
\hline $\begin{array}{l}\text { Banka } \\
\text { Oran } \\
\text { Ortalamas1 }\end{array}$ & 0,4559 & 0,4134 & 0,4666 & 0,4658 & 0,5591 & 0,5490 & 0,4850 \\
\hline $\begin{array}{l}\text { Oran } \\
\text { Kodu }\end{array}$ & & & & & & & \multirow{7}{*}{$\begin{array}{l}\text { Y Oran } \\
\text { Ortalamas1 }\end{array}$} \\
\hline Y1 & 420,7783 & 2571,0206 & 1217,5129 & 3130,2115 & 5556,2903 & 4089,0000 & \\
\hline $\mathrm{Y} 2$ & 0,0101 & 0,0092 & 0,0112 & 0,0077 & 0,0066 & 0,0079 & \\
\hline $\mathrm{Y} 3$ & 0,0407 & 0,0578 & 0,0559 & 0,0459 & 0,0465 & 0,0297 & \\
\hline Y4 & 0,0131 & 0,0102 & 0,0101 & 0,0079 & 0,0050 & 0,0080 & \\
\hline Y5 & 0,0243 & 0,0244 & 0,0187 & 0,0235 & 0,0094 & 0,0062 & \\
\hline Y6 & 2,4112 & 2,6616 & 1,6755 & 3,0406 & 1,4129 & 0,7870 & \\
\hline $\begin{array}{l}\text { Banka } \\
\text { Oran } \\
\text { Ortalamas1 }\end{array}$ & 70,5463 & 428,9640 & 203,2141 & 522,2229 & 926,2951 & 681,6398 & 472,1470 \\
\hline $\begin{array}{l}\text { Oran } \\
\text { Kodu }\end{array}$ & & & & & & & \multirow{9}{*}{$\begin{array}{l}\text { K Oran } \\
\text { Ortalamas1 }\end{array}$} \\
\hline $\mathrm{K} 1$ & 0,0240 & 0,1652 & 0,0780 & 0,1659 & 0,1632 & 0,0385 & \\
\hline $\mathrm{K} 2$ & 0,0019 & 0,0105 & 0,0072 & 0,0107 & 0,0142 & 0,0048 & \\
\hline K3 & 0,1075 & 0,2805 & 0,1452 & 0,3192 & 0,2953 & 0,0600 & \\
\hline K4 & 1,5291 & 2,0450 & 1,7478 & 1,6242 & 1,5953 & 1,7065 & \\
\hline K5 & 0,0011 & 0,0081 & 0,0117 & 0,0067 & 0,0217 & 0,0149 & \\
\hline K6 & 1,3436 & 1,8936 & 1,7645 & 1,4194 & 1,6151 & 2,0259 & \\
\hline K7 & 1,0222 & 1,4768 & 0,8089 & 1,2081 & 0,5554 & 0,3900 & \\
\hline K8 & 0,0024 & 0,0133 & 0,0091 & 0,0146 & 0,0194 & 0,0050 & \\
\hline $\begin{array}{l}\text { Banka } \\
\text { Oran } \\
\text { Ortalamas1 }\end{array}$ & 0,5040 & 0,7366 & 0,5716 & 0,5961 & 0,5349 & 0,5307 & 0,5790 \\
\hline $\begin{array}{l}\text { Oran } \\
\text { Kodu }\end{array}$ & & & & & & & \multirow{6}{*}{$\begin{array}{l}\text { L Oran } \\
\text { Ortalamas1 }\end{array}$} \\
\hline L1 & 0,2520 & 0,2501 & 0,2243 & 0,1611 & 0,1047 & 0,1019 & \\
\hline L2 & 0,3609 & 0,3344 & 0,3048 & 0,2487 & 0,2059 & 0,1667 & \\
\hline L3 & 0,2910 & 0,2801 & 0,2637 & 0,1784 & 0,1193 & 0,1359 & \\
\hline L4 & 0,0489 & 0,0167 & 0,0114 & 0,0042 & 0,0029 & 0,0082 & \\
\hline L5 & 0,3681 & 0,4075 & 0,3873 & 0,3269 & 0,2283 & 0,1677 & \\
\hline $\begin{array}{l}\text { Banka } \\
\text { Oran } \\
\text { Ortalamas1 }\end{array}$ & 0,2642 & 0,2578 & 0,2383 & 0,1839 & 0,1322 & 0,1161 & 0,1987 \\
\hline $\begin{array}{l}\text { Oran } \\
\text { Kodu }\end{array}$ & & & & & & & \multirow{8}{*}{$\begin{array}{l}\text { P Oran } \\
\text { Ortalamas }\end{array}$} \\
\hline $\mathrm{P} 1$ & 0,0643 & 0,0707 & 0,0858 & 0,0759 & 0,0988 & 0,0463 & \\
\hline P2 & 0,9539 & 1,0930 & 0,9841 & 1,1609 & 0,9626 & 1,0009 & \\
\hline P3 & 0,5262 & 0,6261 & 0,5410 & 0,5573 & 0,4294 & 0,5597 & \\
\hline P4 & 0,4738 & 0,3739 & 0,4590 & 0,4427 & 0,5706 & 0,4403 & \\
\hline $\mathrm{P} 5$ & 0,5355 & 0,5442 & 0,6193 & 0,5613 & 0,6095 & 0,4797 & \\
\hline P6 & 0,8263 & 0,8029 & 0,8131 & 0,8737 & 0,9022 & 0,7422 & \\
\hline P7 & 0,0243 & 0,0244 & 0,0187 & 0,0235 & 0,0094 & 0,0062 & \\
\hline $\begin{array}{l}\text { Banka } \\
\text { Oran } \\
\text { Ortalamas1 }\end{array}$ & 0,4863 & 0,5050 & 0,5030 & 0,5279 & 0,5118 & 0,4679 & 0,5003 \\
\hline
\end{tabular}




\section{SONUÇ}

Yapılan hesaplamalar neticesinde;

S Oran Ortalamasının değerinin $\mathbf{0 , 0 6 6 9}$ olduğu görülmüştür. Türkiye Finans Katılım Bankası'nın S Oran Ortalamasının 0,0685, Ziraat Katılım Bankası'nın S Oran Ortalamasının 0,0750 ve Emlak Katılım Bankası'nın S Oran Ortalamasının 0,1132 değerleri ile ortalamanın üzerinde olduğu ve iyi performans gösterdikleri görülmüştür.

Albaraka Türk Katılım Bankası'nın S Oran Ortalamasının 0,0440, Kuveyt Türk Katılım Bankası'nın S Oran Ortalamasının 0,0492 ve Vakıf Katılım Bankası'nın S Oran Ortalamasının 0,0513 değerleri ile ortalamanın altında kaldıkları ve iyi performans sergileyemedikleri görülmüştür.

A Oran Ortalamasının değerinin $\mathbf{0 , 4 8 5 0}$ olduğu görülmüştür. Emlak Katılım Bankası'nın A Oran Ortalamasının 0,5490 ve Ziraat Katılım Bankası'nın A Oran Ortalamasının 0,5591 değerleri ile ortalamanın üzerinde olduğu ve iyi performans gösterdikleri görülmüştür.

Kuveyt Türk Katılım Bankası'nın A Oran Ortalamasının 0,4134, Albaraka Türk Katılım Bankası'nın A Oran Ortalamasının 0,4559, Vakıf Katılım Bankası'nın A Oran Ortalamasının 0,4658 ve Türkiye Finans Katılım Bankası'nın A Oran Ortalamasının 0,4666 değerleri ile ortalamanın altında kaldıkları ve iyi performans sergileyemedikleri görülmüştür.

Y Oran Ortalamasının değerinin 472,1470 olduğu görülmüştür. Vakıf Katılım Bankası'nın Y Oran Ortalamasının 522,2229, Emlak Katılım Bankası'nın Y Oran Ortalamasının 681,6398 ve Ziraat Katılım Bankası'nın Y Oran Ortalamasının 926,2961 değerleri ile ortalamanın üzerinde olduğu ve iyi performans gösterdikleri görülmüştür.

Albaraka Türk Katılım Bankası'nın Y Oran Ortalamasının 70,5463, Türkiye Finans Katılım Bankası'nın Y Oran Ortalamasının 203,2141 ve Kuveyt Türk Katılım Bankası'nın Y Oran Ortalamasının 428,9640 değerleri ile ortalamanın altında kaldıkları ve iyi performans sergileyemedikleri görülmüştür.

K Oran Ortalamasının değerinin $\mathbf{0 , 5 7 9 0}$ olduğu görülmüştür. Vakıf Katılım Bankası'nın K Oran Ortalamasının 0,5961 ve Kuveyt Türk Katılım Bankası'nın K Oran Ortalamasının 0,7366 değerleri ile ortalamanın üzerinde olduğu ve iyi performans gösterdikleri görülmüştür.

Albaraka Türk Katılım Bankası'nın K Oran Ortalamasının 0,5040, Emlak Katılım Bankası'nın K Oran Ortalamasının 0,5307, Ziraat Katılım Bankası'nın K Oran Ortalamasının 0,5349 ve Türkiye Finans Katılım Bankası'nın K Oran Ortalamasının 0,5716 değerleri ile ortalamanın altında kaldıkları ve iyi performans sergileyemedikleri görülmüştür.

L Oran Ortalamasının değerinin $\mathbf{0 , 1 9 8 7}$ olduğu görülmüştür. Türkiye Finans Katılım Bankası'nın L Oran Ortalamasının 0,2383, Kuveyt Türk Katılım Bankası'nın L Oran Ortalamasının 0,2578 ve Albaraka Türk Katılım Bankası'nın L Oran Ortalamasının 0,2642 değerleri ile ortalamanın üzerinde olduğu ve iyi performans gösterdikleri görülmüştür.

Emlak Katılım Bankası'nın L Oran Ortalamasının 0,1161, Ziraat Katılım Bankası'nın L Oran Ortalamasının 0,1322 ve Vakıf Katılım Bankası'nın L Oran Ortalamasının 0,1839 değerleri ile ortalamanın altında kaldıkları ve iyi performans sergileyemedikleri görülmüştür.

P Oran Ortalamasının değerinin $\mathbf{0 , 5 0 0 3}$ olduğu görülmüștür. Türkiye Finans Katılım Bankası'nın P Oran Ortalamasının 0,5030, Kuveyt Türk Katılım Bankası'nın P Oran Ortalamasının 0,5050, Ziraat Katılım Bankası'nın P Oran Ortalamasının 0,5118 ve Vakıf Katılım Bankası'nın P Oran Ortalamasının 0,5279 değerleri ile ortalamanın üzerinde olduğu ve iyi performans gösterdikleri görülmüştür.

Emlak Katılım Bankası'nın P Oran Ortalamasının 0,4679 ve Albaraka Türk Katılım Bankası'nın P Oran Ortalamasının 0,4863 değerleri ile ortalamanın altında kaldıkları ve iyi performans sergileyemedikleri görülmüştür.

Gümüş ve Nalbantoğlu'nun 2015 yılında yapmış olduğu, analizde kullanılan finansal oranlar, çalışmada kullanılan oranlarla benzerlik göstermektedir. Çalışmalarında kamu, yerli, özel, yabancı ve 
katılım bankalarının performans değerlemesini yapmışlardır. Çalışmada katılım bankaları kendi içinde karşılaştırılarak performans değerlendirilmesi açısından ayrılmaktadır.

Çalışmada kullanılan oranlar yine farklı oranlar eşliğinde kullanılarak, farklı çalışmalarda analiz edilerek değerlendirilebilir. Çalışmadan elde edilen sonuçlar banka müşterileri ve paydaşlarına fikir verebileceği düşünülmektedir. Yine farklı yöntemlerin kullanılıp geliştirilmesiyle yeni çalışmalar yapılabileceği aşikardır.

\section{KAYNAKÇA}

Abduh, M., Hasan: M. and Pananjung, A. G. (2013). Efficiency And Performance of Islamic Banks in Bangladesh. Journal of Islamic Banking and Finance, 30(2), 94-106.

Ada, A. A. ve Dalkılıç, N. (2014). Efficiency Analysis in Islamic Banks: A Study For Malaysia and Turkey. Journal of Brsa Banking \& Financial Markets, 8(1), 9-33.

Akgüç, Ö. (1992). 100 soruda Türkiye'de Bankacılık. İstanbul: Gerçek Yayınevi.

Akgüç, Ö. (2012). Banka Finansal Tabloların Analizi. İstanbul: Arayış Basım ve Yayıncılık.

Albaraka Türk Katılım Bankas1- Hesaplar- Birikimli Katılma Hesabı. https://www.albaraka.com.tr/birikimli-katilma-hesabi.aspx. Erişim Tarihi: 04.04.2021.

Alharbi, T., A., (2013). Development of The Islamic Banking System, Determinants of Profitability, and The Performance of Islamic Banks. Doctoral Dissertation, La Trobe University.

Aktepe, İ. E. (2010). İslâm Hukûku Çerçevesinde Finansman ve Bankacılık. Tkbb Kitapları İstanbul: Erkam Matbaası.

Akdoğan, N. ve Tenker, N., (2007). Finansal Tablolar ve Mali Analiz Teknikleri (12. Baskı), Gazi Kitabevi, Ankara.

Alam, M. N. (2000). Islamic Banking in Bangladesh: A Case Study of IBBL. International Journal of Islamic Financial Services, 1(4), 10-29.

Alkheil, M., A., (2012). Ethical Banking and Finance: A Theoretical and Empirical Framework For The Crosscountry and Inter-Bank Analysis of Efficiency, Productivity, and Financial Performance. Doctoral Dissertation, Hohenheim University.

Apak ve Açıkgöz, A. F. (2011). Türkiye'de Katılım Bankacılı̆̆ının Bankacılık Sektöründeki Yeri ve Finansal İstikrara Katkıs1, Mufitad Dergisi, Sayı 1, 70- 85.

Ariff, M., (2014). "Whither Islamic Banking?". The World Economy, 37 (6), 733-746.

Ayrıçay, Y., Yardımcıoğlu, M., and Demir, B., (2014). Mevduat ve Katılım Bankalarının Finansal Performanslarının Karşılaştırılması. Kahramanmaraş Sütçü İmam Üniversitesi İktisadi ve İdari Bilimler Fakültesi Dergisi, 4(2), 1-18.

Aytekin, S. ve Sakarya, Ş. (2013). BIST'deki Mevduat Bankalarının Finansal Performanslarının 2001 ve 2008 Finansal Krizleri Çerçevesinde CAMELS Derecelendirme Sistemi ile Değerlendirilmesi. Abant İzzet Baysal Üniversitesi Sosyal Bilimler Enstitüsü Dergisi, 25-58.

Babar, H. Z. and Zeb, G. (2011). Camels Ratıng System for Banking Industry in Pakıstan, Umea University, Umea School of Business Spring Semester 2011 Master Thesis, Sweden.

Bashir, A. M. (2003). Determinants Of Profitability in Islamic Banks: Some Evidence From The Middle East. Islamic Economic Studies, 11(1), 31-57. Dağıtım.

Başkaya, D. ve Avcı, A. B. (2011). Veri Zarflama Analizi. Bursa: Dora Basım- Yayın-

Bayındır, S., (2005). Bir Finansman Yöntemi Olarak Kullanılan Sermaye Ortaklığının İslâm Hukuku Açısından Değerlendirilmesi. Usûl İslam Dergisi, 3 (3), 139-157.

Bayındır, S. (2015). Fıkhi ve İktisadi Açıdan İslami Finans (Para ve Sermaye Piyasaları), Süleymaniye Vakfı Yayınları, Yayın No.21, İmak Ofset Basım Yayın, İstanbul. 
Billah, M. M., (2007). "Islamic Banking and the Growth of Takaful". In Hassan M. K. And Lewis M. K. "Handbook of Islamic Banking", 401- 418), Edward Elgar Publishing Limited, USA.

Bitar, M., (2014). Banking Regulation, Stability and Efficiency of Islamic Banks: What Works Best? A Comparison With Conventional Banks. Doctoral Dissertation Grenoble University.

Bank Negara Malaysia, (BNM), (2010). Shariah Resolutions İn İslamic Finance. www.bnm.gov.my Erişim Tarihi:2.12.2020 https://www.islamicfinance.com/wpcontent/uploads/2015/01/Shariah-Resolutions-2nd-Edition-En.pdf

Beki, A., (2005). İslam’da Güncel Ticari Meseleler, Bekke Yayınları, 2. Basım, Kayseri.

Canbaz, M., (2012). Bankacılık Giriş ve İlkeleri. (1. Baskı). İstanbul: Beta Basım Yayıncılık.

Christopoulos, A. G., Mylonakis, J., and Diktapanidis, P. (2011). Could Lehman Brothers'Collapse Be Anticipated? An Examination Using CAMELS Rating System. International Business Research, 11-19.

Çetiner, E. (2000). İşletmelerde Mali Analiz. Ankara. Gazi Kitabevi.

Çabuk, A. ve Lazol, İ. (2012). Mali Tablolar Analizi. Bursa: Ekin Yayınevi.

Çağıl, G. ve Mukhtarov, S. (2014). Azerbaycan Ticari Bankacılık Sektörünün Camels Yöntemi ile Performans Analizi. Marmara Üniversitesi Öneri Dergisi, 77-94.

Çambel, H. (2017). Katılım Bankaları Tarafından Uygulanan Fon Toplama ve Fon Kullandırma Yöntem ve Esasları, Kaya, F. (Ed.) içinde, Katılım Bankacılı̆̆ı, İstanbul, Beta Basım, $125-145$.

Doğan, M. (2015). Comparıson of Financial Performance of Partıcıpatıon Banks in Turkey. Journal of Economics Finance and Accounting, 2 (4), 0-0.

Etab, M., M., (2016). The Internal And External Contingent Factors That Affect The Determination of Profitability in Islamic Banks in Comparison to Conventional Banks in Egypt. Doctoral Dissertation, De Montfort University.

Firdaus, F., and Hosen, M., N., (2013). Efficiency of Islamic Banks Using Two Stage Approach of Data Envelopment Analysis. Bulletin of Monetary, Economics and Banking.

Görüş, M. Ş., and Özgür, Ö. (2016). Türkiye'de İslami Bankaların Kârlılığının Belirleyicleri: Banka İçi Faktör Analizi, Sakarya İktisat Dergisi, 5(2), 1-13.

Güney, S. ve Saka Ilgın, K. (2016). Finansal Krizlerin Bankaların Performanslarına Etkisi: Türk Mevduat Bankalarında Camels Modelinin İncelenmesi ve Örnek Bir Uygulama. Dokuz Eylül Üniversitesi Sosyal Bilimler Enstitüsü Dergisi, 303-331.

Güngören M. (2013). Bir Finansal Enstrüman Olarak Sukuk Katılım Bankalarına Uyum Modellemesi. İstanbul: İstanbul Ticaret Odas1 Yayınları.

Gümüş, F. B. ve Nalbantoğlu, Ö. (2015). Türk Bankacıllk Sektörünün Camels Analizi Yöntemiyle 2002-2013 Y1lları Arasında Performans Analizi. Afyon Kocatepe Üniversitesi İktisadi ve İdari Bilimler Fakültesi Dergisi, 17(2), 83- 106. 49-78.

Hassan, M. K. (2006). The X-Efficiency in Islamic Banks. Islamic Economic Studies, 13(2),

Islamic Financial Services Board, (IFSB), (2014). Prospects and Challenges in The Development of Islamic Finance For Bangladesh.

Ismail, F., Shabri Abd. Majid, M., and Rahim, R. A., (2013). Efficiency of Islamic and Conventional Banks in Malaysia. Journal of Financial Reporting and Accounting, 11(1), 92- 107.

Iqbal, M. ve Molyneux, P., (2005). Thirty Years of Islamic Banking: History, Performance, and Prospects, Palgrave Macmillan; 1st ed. 
Kalaycı, İ., (2013). Katılım Bankacılığı: Mali Kesimde Nasıl Bir Seçenek? Uluslararası Yönetim İktisat ve İşletme Dergisi, 9(19), 51-74.

Kettell, B. (2011). Case Studies in Islamic Banking And Finance. Case Questions \& Answers, John Wiley \& Sons Ltd, United Kingdom.

Kevser, M. (2021). Banka Türlerinin Karşılaştırmalı Finansal Performans Analizi: Türkiye İçin Ampirik Bir Araştırma. Muhasebe Bilim Dünyası Dergisi, 23 (1), 61-80.

Khorshid, A. (2004). Islamic İnsurance: A Modern Approach To Islamic Banking. Routledge Curzon, New York.

Mirakhor, A., and Zaidi, I., (2007). Profit-and-Loss Sharing Contracts İn Islamic Finance. Edward Elgar Publishing.

Moin, M., (2008). Performance of Islamic Banking and Conventional Banking in Pakistan: A Comparative Study. Mater Thesis, University of Skövde, School of Technology and Society.

Nimalathasan, B. (2008). A Comparatıve Study Of Financial Performance Of Bankıng Sector In Bangladesh - An Application Of Camels Ratıng System. Annals of University of Bucharest, Economic and Administrative Series, 141-152.

Okumuş, H. Ş., (2005). "Interest-Free Banking in Turkey: a Study of Customer Satisfaction and Bank Selection Criteria". Journal of Economic Cooperation, 26 (4), 51-86.

Omari, O., O., (2011). Measuring Islamic Banks'Efficiency Using Data Envelopment Analysis (Dea) and Financial Ratio Analysis (Fra): The Case of Jordanian Islamic Banks During The Period 2005-2009. Master's Thesis, Yarmouk University.

Öztürk, N., (2011). Para, Banka, Kredi, Ekin Yayınc1l1k, İstanbul.

Özulucan, A. ve Deran, A. (2009). Katılım Bankacılığı Geleneksel Bankaların Bankacılık Hizmetleri ve Muhasebe Uygulamaları Açısından Karşılaştırılması. Mustafa Kemal Üniversitesi, Sosyal Bilimler Enstitüsü Dergisi, 6(1): 85-108.

Parlakkaya, R. ve Çürük: A., (2011). Finansal Rasyoların Katılım Bankaları ve Geleneksel Bankalar Arasında Bir Tasnif Aracı Olarak Kullanımı: Türkiye Örneği. Ege Akademik Bakış Dergisi, 11(3), 397-405.

Piccinelli, G., M., (2010) The Provision and Management of Savings: The Client Partner Model. Edward Elgar Publishing.

Qureshi, M. A. and Shaikh, M. (2012). Efficiency of Islamic and Conventional Banks in Pakistan: A Non-Parametric Approach. International Journal of Business and Management, 7(7), 40.

Sakarya, Ş. (2010). Camels Derecelendirme Sistemine Göre İmkb'deki Yerli ve Yabanc1 Sermayeli Bankaların Karşılaştırmalı Analizi. Akademik Araştırmalar ve Çalışmalar Dergisi, 7-21.

Schéele, M. V. (2002). Islamic Bankıng Law Concept, Practice \& Effects, Master Thesis, Faculty of Law University of Lund.

Sermaye Piyasaları Araştırma ve Uygulama Merkezi (SERPAM), (2013). İslami Finans Kavramı Ürünler, Dünyada ve Türkiye'de Gelişimi ve Geleceği, Araştırma Notları 1. https://tkbb.org.tr/Documents/Yonetmelikler/Islami_Finans.pdf Kitapevi.

Söyler, İ., (2014). Hukuki ve Mali Boyutlarıyla Sukuk (Kira Sertifikaları). Ankara, Gazi

Sufian, F. (2007). The Efficiency Of Islamic Banking İndustry: A Non-Parametric Analysis With Non-Discretionary İnput Variable. Islamic Economic Studies, 14(1-2), 53-78.

Sufian, F., Kamarudin, F. and Noor, N. H. H. M., (2012). Determinants Of Revenue Efficiency İn The Malaysian Islamic Banking Sector. Journal Of King Abdulaziz University: Islamic Economics, 25(2), 195-224. 
Tiby, A. M. E. (2011). Islamic Banking: How To Manage Risk and İmprove Profitability. John Wiley \& Sons, United Kingdom.

Toraman, C., Ata, H. A. ve Buğan, M. F. (2015). Mevduat ve Katılım Bankalarının Karşılaştırmalı Performans Analizi. Cumhuriyet Üniversitesi İktisadi ve İdari Bilimler Dergisi, 16(2), 301-310.

Tunç, H. (2010). Katılım Bankacılığı Felsefesi, Teorisi ve Türkiye Uygulaması, Nesil Yayınevi, İstanbul.

Tunç, H. (2010). Katılım Bankacılığı. İstanbul: Nesil Yayınları.

Türker Kaya, Y. (2001), Türk Bankacılık Sektöründe CAMELS Analizi, Bankacılık Düzenleme ve Denetleme Kurumu, MSPD Çalışma Raporları: 2001/6.

Türkiye Katılım Bankalar Birliği., (2015). Katılım Bankaları 2015. https://tkbb.org.tr/Documents/Yonetmelikler/KATILIM_2015_TR_final.pdf Erişim Tarihi 25.12.2020.

Türkiye Katılım Bankaları Birliği Yayınları (TKBB), (2019). Yaşayan ve Gelişen Katılım Bankacılığ , Yayın No: 12, İstanbul.

T.C. Resmî Gazete, 20 Eylül 2001, 24529. https://www.resmigazete.gov.tr/eskiler/2001/09/20010920.htm\#4 Erişim Tarihi: 04.04.2021.

T.C. Resmî Gazete, $18 \quad$ Eylül 2018, Sayı: 30569. https://www.resmigazete.gov.tr/eskiler/2018/10/20181018-2.htm. Erişim Tarihi: 04.04.2021.

Yanık, R, Sumer, S. (2019). Akademisyenlerin İslami Bankacılık Algısı. Atatürk Üniversitesi Sosyal Bilimler Enstitüsü Dergisi, 23 (3), 1177-1190

Yanpar, A. (2015). İslami Finans İlkeler, Araçlar ve Kurumlar. İstanbul, Scala Yayıncılık.

Yudistira, D. (2004). Efficiency İn Islamic Banking: An Empirical Analysis Of 18 Banks. Islamic Economic Studies, 12 (1), 2- 19.

Ziraat Katılım Bankas1, Bireysel- Einansman ünleri, https://www.ziraatkatilim.com.tr/bireysel/finansman-urunleri. Erişim Tarihi: 05.04.2021.

https://islamansiklopedisi.org.tr/muzaraa Erişim Tarihi: 25.12.2020

http://www.tkbb.org.tr/banka-genel-bilgileri\#1703 Erişim Tarihi: 25.11.2020

http://www.tkbb.org.tr/mukayeseli-tablolar Erişim Tarihi: 25.11.2020

http://www.tkbb.org.tr/tarihce Erişim Tarihi: 25.11.2020 